Review

\title{
Emerging and Persistent Pollutants in the Aquatic Ecosystems of the Lower Danube Basin and North West Black Sea Region-A Review
}

\author{
Carmen Lidia Chițescu ${ }^{1}$, Antoaneta Ene ${ }^{2, *} \mathbb{0}$, Elisabeta-Irina Geana ${ }^{3}{ }^{\mathbb{D}}$, Aida Mihaela Vasile ${ }^{4}$ \\ and Corina Teodora Ciucure ${ }^{3}$ \\ 1 Faculty of Medicine and Pharmacy, Dunarea de Jos University of Galati, 35 A.I. Cuza Street, \\ 800010 Galati, Romania; carmen.chitescu@ugal.ro \\ 2 INPOLDE Research Center, Faculty of Sciences and Environment, Dunarea de Jos University of Galati, \\ 47 Domneasca Street, 800008 Galati, Romania \\ 3 National Research \& Development Institute for Cryogenics and Isotopic Technologies (ICSI Rm. Vâlcea), \\ 4th Uzinei Street, 240050 Râmnicu Vâlcea, Romania; irina.geana@icsi.ro (E.-I.G.); \\ corina.ciucure@icsi.ro (C.T.C.) \\ 4 Faculty of Food Science and Engineering, Dunarea de Jos University of Galati, 111 Domneasca \\ Street, 800201 Galati, Romania; Aida.Vasile@ugal.ro \\ * Correspondence: Antoaneta.Ene@ugal.ro
}

Citation: Chițescu, C.L.; Ene, A.; Geana, E.-I.; Vasile, A.M.

Ciucure, C.T. Emerging and Persistent Pollutants in the Aquatic Ecosystems of the Lower Danube Basin and North West Black Sea Region-A Review. Appl. Sci. 2021, 11, 9721. https://doi.org/10.3390/app11209721

Academic Editor: Marek Gołębiowski

Received: 29 August 2021

Accepted: 10 October 2021

Published: 18 October 202

Publisher's Note: MDPI stays neutral with regard to jurisdictional claims in published maps and institutional affiliations.

Copyright: (c) 2021 by the authors. Licensee MDPI, Basel, Switzerland. This article is an open access article distributed under the terms and conditions of the Creative Commons Attribution (CC BY) license (https:// creativecommons.org/licenses/by/ $4.0 /)$

\begin{abstract}
The tremendous impact of natural and anthropogenic organic and inorganic substances continuously released into the environment requires a better understanding of the chemical status of aquatic ecosystems. Water contamination monitoring studies were performed for different classes of substances in different regions of the world. Reliable analytical methods and exposure assessment are the basis of a better management of water resources. Our research comprised publications from 2010 regarding the Lower Danube and North West Black Sea region, considering regulated and unregulated persistent and emerging pollutants. The frequently reported ones were: pharmaceuticals (carbamazepine, diclofenac, sulfamethoxazole, and trimethoprim), pesticides (atrazine, carbendazim, and metolachlor), endocrine disruptors-bisphenol A and estrone, polycyclic aromatic hydrocarbons, organochlorinated pesticides, and heavy metals $(\mathrm{Cd}, \mathrm{Zn}, \mathrm{Pb}, \mathrm{Hg}, \mathrm{Cu}, \mathrm{Cr})$. Seasonal variations were reported for both organic and inorganic contaminants. Microbial pollution was also a subject of the present review.
\end{abstract}

Keywords: pharmaceuticals; endocrine disruptors; persistent organic pollutants; metals; microbiological contamination; monitoring survey

\section{Introduction}

With a total length of $2780 \mathrm{~km}$, the Danube River crosses 10 countries and 4 capitals and eventually runs into the Black Sea through the Danube Delta, the largest European wetland [1]. Due to its biodiversity, The Danube Delta, together with the Razim-Sinoe lagoon, is stated as an UNESCO World Heritage Biosphere Reserve [2]. The Danube basin on Romanian territory is the largest, compared with other countries of the Danube River Basin [1].

Surrounded by six coastal countries-Bulgaria, Georgia, Romania, Russia, Turkey, and Ukraine-the Black Sea is one of the largest inland water basins. Being almost entirely isolated from the world's oceans, the Black Sea is the largest natural anoxic water basin in the world [3]. The Black Sea is also a reservoir for the contaminants from multiple sources, among which Danube, the Dniester, the Dnieper, and the Don are the most significant [3].

Due to the location and climatic and historical conditions, the Lower Danube and Black Sea basins constitute an unique ecosystem [4]. In Eastern Europe, the rapid development of small industry tourism activities and urban area, together with a decrease of the intensive 
farming, led to the frequent change in a pollutant profile. High industrial pollution inputs from tributaries and poor control of the discharges significantly affected the Lower Danube's water quality [5]. Due to fish farming, reed harvesting and, more recently, increasing of the recreational and tourist industry, disturbances in the aquatic ecosystems of the Danube Delta have occurred [1].

Surface waters provide important services, including drinking water, irrigation, hydropower, tourism, fishing, and navigation. Crossing a territory inhabited by about 83 million people, the Danube River is permanently highly exposed to anthropogenic contamination [5]. As the contamination of water bodies pose significant public health risks, water framework policies aim to improve the management of water resources. Danube River Protection Convention (1994) represents the overall legal instrument for water management and transboundary co-operation in the Danube River Basin [6]. According to the requirements of the European Water Framework Directive (WFD), a process of selecting and monitoring of the relevant pollutants in the river basin started in 2001 [7]. Coordinated by the International Commission for the Protection of the Danube River (ICPDR), Joint Danube Surveys (JDSs) have been conducted on the Danube river basin every six years from 2001-2020 (JDS 1-4), providing reliable and comprehensive data on water quality and pollution level [8].

Furthermore, several surveys along shorter sections of the Danube River monitoring certain contaminants classes relieved dynamic and regional particularities of the pollution [9-14]. Thus, different monitoring studies identified several classes of contaminants such as: pharmaceuticals $[10,13,15,16]$, personal care products $[17,18]$, endocrine disruptors [19-23], pesticides [2,22], polycyclic aromatic hydrocarbons [11,22], polychlorinated biphenyls [22], heavy metals [22,24,25], and microbiological contaminants [8].

However, past surveys, including JDSs 1-3, regarded a limited number of compounds and classes. Currently, due to the development of the advanced analytical technologies based on high-resolution mass spectrometry together with large databases such as NORMAN network, wide scope non-target screenings have been conducted, providing a broader perspective on the Danube pollution phenomenon [26,27].

The present review aimed to systematize recent monitoring studies in the Lower Danube and North West Black Sea area in order to identify the current research status and layout future research challenges; such surveys provide policy-relevant data. Comparative discussions on the pollution of other rivers elsewhere are presented.

Contaminants classes such as pharmaceuticals (PhACs), personal care products (PCPs), endocrine disruptors (EDs), pesticides, persistent organic pollutants (POPs) such as polychlorinated biphenyls (PCBs), organochlorine pesticides (OCPs), or polycyclic aromatic hydrocarbons (PAHs), but also heavy metals, analysed in matrices such as groundwater, surface water, sediments and biota, were considered. Microbiological contamination is also one of the most important health-related water quality problems in the Lower Danube region due to minimal wastewater treatment applied in smaller cities and villages on the tributaries. Therefore, microbial pollution was also a subject of the present review.

The paper was based on a systematic search in Web of Science (Clarivate Analytics) and Google Scholar for papers published between 2010 and 2021 on the selected pollutants, using as keywords terms including: "pharmaceuticals", "endocrine disruptors", "pesticides", "metals", "bisphenols", "hormones", "personal care products", "polychlorinated biphenyls", "polycyclic aromatic hydrocarbons", "organochlorinated pesticides", "microbiological pollutants" for pollutants, and "ground water", "surface water", "river water", "sea water", "coastal water", "sediments", "fish", and "biota" for the environmental matrix. Studies dealing with sampling campaigns, seasonal monitoring, temporal monitoring (e.g., same sampling points in different years) or spatial monitoring (e.g., different locations in the same period), were considered. In some of the studies, sampling was performed before 2010, the publication of the result occurring later.

Our study covered the section of the Danube River extended from Novi-Sad, Serbia (river km 1254) to the Danube mouth including the Danube Delta and the north-west Black 
Sea coast surrounded by Bulgaria, Romania, and Ukraine. Catchment's area of the Danube and Black Sea basins on the territories of Serbia, Bulgaria, Romania, Republic of Moldova, and Ukraine were included. The main Danube tributaries along the selected section are: the Tisza, the Sava, the Velika Morava, the Jiu, the Iskar, the Olt, the Yantra, the Argeş, the Siret, and the Prut River (Figure 1). In this survey, the Dniester River, a transboundary river between Ukraine and Republic of Moldova, being the second largest river that flows into the NW Black Sea through an estuary (Dniester Liman) and a target aquatic ecosystem in several projects implemented in the Black Sea Basin, was also included.

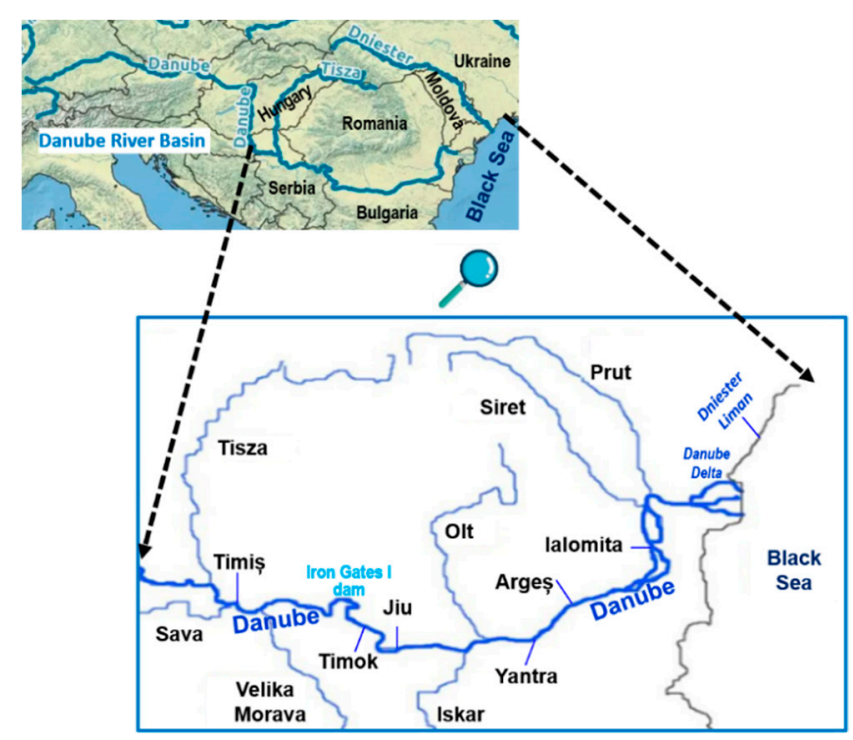

Figure 1. The study area in the Danube River and NW Black Sea Basins.

\section{Contaminants of Emerging Concern (CECs)}

Contaminants of emerging concern (CECs) is a general term for the organic pollutant(s) including: human and veterinary pharmaceuticals (PhACs), endocrine disruptors (EDs) as bisphenols and steroids hormones, personal care products (PCPs), illegal drugs, antifungals, biocides, pesticides, herbicides, surfactants, and nanomaterials [28]. The term of CECs characterizes classes of unregulated or not completely regulated chemicals [29]. CECs are generally chemicals previously known to be present in the environment but exhibiting new documented impacts, recombination of known chemicals or mixtures of chemicals which, in combination, are hazardous for the environment, pharmaceuticals, and pharmaceuticals metabolites [30]. The main contamination sources are untreated wastewater, the wastewater treatment plants, waste of medical centers, animals and livestock, fertilization practice with manure, poorly treated raw materials, and different industries $[29,30]$. Potential concerns of the environment contamination with CECs include abnormal physiological processes and reproductive impairment of aquatic biota, the development of antibiotic-resistant bacteria, and the potential increased toxicity of chemical mixtures [29,31].

Due to the large number and diversity, the continuous discharge and long-term persistence of CECs pose a significant challenge to the scientific community and policy regulators. Prioritization criteria have been set according to the occurrence, exposure routes, chemical properties, toxicological relevance as results of in vitro and in vivo studies, current regulator state, and current research [31]. REACH regulatory approach [32] and the NORMAN prioritization focused on eco-toxicity endpoints [33] are the most common methodologies applied in Europe. However, the lack of information on hazard and risk of CECs makes the prioritisation process a research field with many unknowns [34].

Currently, according to the European Union Directive 2013/39/EU [35] the Watch List of Decision 2018/840/EU [36] and recent Directive 2020/1161/EU [37], several CECS including non-steroidal anti-inflammatory drug (NSAID) diclofenac, macrolide antibiotics, synthetic estrogen 17-ethinylestradiol (EE2), two natural estrogens, estrone (E1) and 17 $\alpha$ - 
estradiol (E2), methiocarb, metaflumizone, several neonicotinoids, and azoles antifungals should be monitored in Europe in surface water. Acceptable method detection limits (as lowest PNEC) were set by the European Commission as Environmental Quality Standards (EQS) $[36,37]$.

Among CECs, pharmaceuticals, PCPs, EDs, and pesticides (other than organochlorine pesticides) were more often monitored in the Danube River basin and represent the subject of the research in the present review.

\subsection{Pharmaceuticals (PhACs)}

Although the occurrence of PhACs has been documented since 20 years ago in the European environment, these chemicals are not included among those to be monitored [38]. Pharmaceutical compounds most often identified in the aquatic environment belong to several classes of human and veterinary antibiotics and human prescription and nonprescription drugs such as NSAIDs, $\beta$-blockers, blood lipid regulators, antiepileptics, analgesics, and antidepressants $[15,39,40]$.

The occurrence of pharmaceuticals in the Lower Danube basin has been investigated since 2001. A number of PhACs, among which metronidazole, ambroxole, clotrimazole, paracetamol, and metamizole were monitored within the JDS1 sampling campaign (AugustSeptember 2001). From 2005, independent studies also reported the presence of PhACs in the Danube waters [41,42]. The next JDS 2 sampling campaign (September 2007) monitored NSADs ketoprofen, naproxen, ibuprofen, diclofenac, antiepileptic carbamazepine, caffeine, and sulfamethoxazole and reported high concentration of carbamazepine around Budapest and in Tisa and Sava tributaries [43]. After 2010, the number of published studies considerably increased and the studies have become more complex, comprising a higher number of compounds $[10,15]$. As the consequence of the improvements in analytical instrumentation sensitivity that have made it possible to detect extremely low concentrations, the number of pharmaceuticals substances detected in the environmental matrices has been dramatically increased $[15,40]$.

A number of 14 published studies have been identified concerning qualitative and quantitative monitoring studies in Lower Danube basin including tributaries and the Danube Delta during 2010-2021 (Table 1). One publication describing a comprehensive study on the CECs on Dniester River was identified. No publication on the monitoring of pharmaceuticals in the North-West Black Sea coast was found. Environmental matrices such as surface water samples (13 publications), ground water (3 publications), drinking water (1 publication), and sediment ( 3 publications) were investigated. The majority of the studies are based on 'grab-sampling' for the surface water. For sediments samples, a gravity corer [44] or a steel hand bucket for the river bottom sites was used [39]. Solid phase extraction (SPE) has been used for analyte extraction, concentration and purification for the water samples. Ultrasonic-assisted extraction (UAE) followed by SPE purification was used in case of solid samples. Liquid chromatography (LC) was employed for analysis of PhACs in all selected studies.

Mass spectrometry (MS) and tandem MS/MS detection with electrospray ionization (ESI) and atmospheric pressure chemical ionization (APCI) represented the most common technique. High-resolution mass spectrometry (HRMS) was used in four studies, enabling a new acquisition approach as non-target Data Independent Acquisition (DIA) [26]. 
Table 1. Summary of the publication during 2010-2021 on the area of Lower Danube and North-West Black Sea Basins concerning pharmaceuticals contaminants.

\begin{tabular}{|c|c|c|c|c|}
\hline $\begin{array}{l}\text { Sampling Site/Sampling Moment } \\
\text { (Data) }\end{array}$ & Monitored Contaminants & Analytical Approach & $\begin{array}{l}\text { Relevant Environmental Concentrations Range } \\
\text { for the Detected Compunds in Analysed } \\
\text { Matrices }\end{array}$ & Ref. \\
\hline $\begin{array}{l}\text { Middle and lower sector of the Danube } \\
\text { River and its tributaries } \\
\text { August-September } 2013 \text { (JDS3) }\end{array}$ & $\begin{array}{l}\text { Five compounds, including: } \\
\text { carbamazepine, its metabolite 10,11- } \\
\text { dihydro-10,11-dihydroxy-carbamazepine, } \\
\text { sulfamethoxazole and diclofenac }\end{array}$ & $\begin{array}{l}\text { SPE-UHPLC-QqQ- } \\
\text { MS-MS, } \\
\text { MRM mode }\end{array}$ & $\begin{array}{l}\text { Surface waters (ng/L): Carbamazepine (20-68, max } \\
\text { in Arges river); Sulfamethoxazole (20-141, max. in } \\
\text { Arges river); Diclofenac ( } 2-255 \text {, max. in Arges } \\
\text { river); Naproxen (1-9); } \\
\text { Ibuprofen (5-27) }\end{array}$ & [45] \\
\hline $\begin{array}{l}\text { Along the Danube banks of Novi } \\
\text { Sad/July and November 2011, March } \\
\text { and May 2012, seasonal monitoring }\end{array}$ & $\begin{array}{l}\text { Four compounds, including: caffeine, } \\
\text { sulfamethoxazole, chloramphenicol, } \\
\text { tiamuline }\end{array}$ & SPE-HPLC-DAD & $\begin{array}{l}\text { Surface waters (ng/L): Caffeine (15.91-306, mean } \\
40.6)\end{array}$ & [46] \\
\hline Danube, Novi Sad region/Spring, 2012 & $\begin{array}{l}47 \text { compounds, including: analgesics, lipid } \\
\text { regulators, psychiatric drugs, diuretics, } \\
\text { antidiabetic, antihypertensives, NSAIDs }\end{array}$ & $\begin{array}{l}\text { SPE-UHPLC-Q-TRAP MS, turbo ion } \\
\text { spray source }\end{array}$ & $\begin{array}{l}\text { Surface waters (ng/L): Ibuprofen (<LOQ-346 in } \\
\text { surface water, } 92 \text { in groundwater); } \\
\text { 10,11-Epoxycarbamazepine (<LOQ-932 in surface } \\
\text { water, } 128 \text { in drinking water); Hydrochlorothiazid } \\
\text { (54.55); Valsartan (89.6); Erythromycin (292); } \\
\text { Cefalexin (283), Hydrochlorothiazide (<LOQ-164); } \\
\text { Atenolol (<LOQ-50.6); Metoprolol (<LOQ-26.3); } \\
\text { Clarithromycin (<LOQ-616); Cefalexin (283); } \\
\text { Carbamazepine (<LOQ-35.5) }\end{array}$ & [15] \\
\hline $\begin{array}{l}\text { Danube River downstream of Novi } \\
\text { Sad/seasonal monitoring, } 2016\end{array}$ & $\begin{array}{l}\text { Seven compounds, including: caffeine, } \\
\text { carbamazepine, diazepam and metabolite } \\
\text { desmethyldiazepam benzotriazole } \\
\text { sulfamethoxazole, ibuprofen }\end{array}$ & $\begin{array}{l}\text { SPE-LCQqQ MS-MS, ESI source, } \\
\text { MRM mode }\end{array}$ & $\begin{array}{l}\text { Surface waters (ng/L): Caffeine (5.27-256); } \\
\text { Carbamazepine (3.94-22.9); Ibuprofen (3.32-60.1); }\end{array}$ & [47] \\
\hline $\begin{array}{l}\text { Danube River and four sampling sites } \\
\text { in tributaries Tisa, Sava, Morava and } \\
\text { Pek near confluence with the } \\
\text { Danube/2009-2010 }\end{array}$ & $\begin{array}{l}10 \text { compounds, including: penicillin } \\
\text { antibiotics, } \\
\text { benzodiazepines carbamazepine diclofenac, } \\
\text { metamizole metabolites }\end{array}$ & SPE-LC-QqQ MS-MS & $\begin{array}{l}\text { Surface waters (ng/L): Metamizole metabolite } \\
\text { 4-AAA (150, in ground water and } 247 \text { in surface } \\
\text { water in Tisa river); Metamizole metabolite 4-FAA } \\
\text { ( } 327 \text { in surface water-Morava); Trimethoprim ( } 223 \\
\text { in surface water, Danube); Carbamazepine ( } 94 \text { in } \\
\text { surface water, Tisa river); Lozarepam ( } 34 \text { ) }\end{array}$ & [48] \\
\hline
\end{tabular}


Table 1. Cont.

\section{Sampling Site/Sampling Moment} (Data)

Two sampling points on the Danube River, in the cities of Novi Sad and Kovin (Serbia) and three sampling sites from Danube's major tributaries: the Tisa River, the Sava River, the Morava River/Not mentioned 13 compounds, including: penicillins,
sulfamethoxazole,

trimethoprim, macrolides,

aminophenazone and metabolites,

benzodiazepines, carbamazepine
Analytical Approach

Analytical Approach

Monitored Contaminants

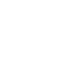

Middle and low of the Danube River and its tributaries Morava, Tisza, Sava, Velika Morava, Arges, Olt, Iskar,

Rusenski Lom (not on map), Yantra, and Prut/August 2007

\begin{tabular}{l}
\hline $11 \mathrm{~km}$ upstream from the \\
Iron Gate I dam/ \\
August-September 2007, JDS2 \\
\hline 16 sampling locations along the \\
Romanian side of the Danube and its \\
three main tributaries, Jiu, Olt and \\
Arges rivers/ \\
February, April and June 2014 and \\
October 2015 \\
\hline
\end{tabular}

15 sites in the Mures,

Six compounds, including: sulfamenthoxazole, carmabazepine, caffeine, ibuprofen, diclofenac, bezafibrat

19 compounds, including: antihypertensive,

19 compounds, including: antihyp
macrolide antibiotics, sedatives, antiepileptics, anticoagulants, NSADs

35 compounds, including: diuretics, NSAIDs, antibiotics, analgesics, lipid regulators, caffeine, anticonvulsivants
SPE-UHPLC-QqQ MS-MS, ESI source, MRM mode
SPE-UHPLC-Q-IT MS, SRM mode

UAE and SPE

UHPLC Q-IT-, ESI and APCI source

\section{Relevant Environmental Concentrations Range for the Detected Compunds in Analysed}

\section{Matrices}

Surface waters (ng/L): Trimetoprim (7-212 in

surface water, max. in Morava river);

surface water, max. in Morava river);
4-formylaminoantipyrine (4-FAA) (9-186, in

surface water, max. in Tisa river);

4-acetylaminoantipyrin (4-AAA) (20-512, in

surface water, max. in Morava river); Carbamazine

(8-94, in surface water, max. in Tisa river);

Groundwaters (ng/L): Azithromycin (12-68, in

ground water, max. in Danube);

Sediment (ng/g): Diazepam (48)

Surface waters (ng/L): Sulfametoxazole (30-204,

max. in the Arges River); Ibuprofen (5-34, max. in

the Velika Morava river); Carbamazepine (27-945, max. in the Arges River); Diclofenac $<5 \mathrm{ng} / \mathrm{L}$

Sediment core samples (Max deep $70 \mathrm{~cm})(\mathrm{ng} / \mathrm{g})$ :

Sulfamethoxazole (0.5-30); Erytromycin (6.8-36.9);

Carbamazepine (0.5-0.9); Clopidogrel (0.1-13.9)

[44]

Surface waters (ng/L): Caffeine (28.3-128);

Carbamazepine (5.4-15.4);

SPE, LC-QqQMS-MS

Target analysis

in MRM mode

Clarithromycin (1.2-23.2); Cephalexin (5.6-17.8);

Sulfamethoxazole (3.2-15.7); Trimethoprim

(1.3-11.1); Naproxen (2.4-106); Ibuprofen (2-27.2);

Diclofenac (0.8-7.5)

10 compounds: carbamazepine,

10,11-dihydrocarbamazepine, enalapril,

River (Tributary of Tisza, Danube basin) on exit from the Romanian territory/

2018

furosemide enalaprilat, ibuprofen, and methabolites

Surface waters (ng/L): Enalaprilat (1.73-23.16);

Enalapril (1.16-14); Furosemide (7.88-444.63);

Carbamazepine (7.16-643.31); Ibuprofen

(1.65-117.14); Carboxi-ibuprofen (6.74-391.16);

2-hydroxyibuprofen hidroxyibuprofen (2.89-68.29)

SPE-LC-QqQ MS 
Table 1. Cont.

\section{Sampling Site/Sampling Moment} (Data)

16 samples from Danube river and from three of the main effluents: Siret, Olt, Arges; 4 samples from Danube Delta/ May, June, August and October 2014

3 samples from the Danube river and 2 samples from tributary Siret and Prut River/

April 2012
Along the 250-km-long stretch of the Prut River basin (Danube

tributary)/Three sampling campaigns:

May and November 2011, and June 2012
Monitored Contaminants

Analytical Approach

36 compounds, including: macrolides,

benzimidazole, tranquilizers, macrolides, sulfonamides, quinolones, penicillins,

tetracyclines, NSAIDs, antiepileptic, lipid regulator, coccidiostats
Relevant Environmental Concentrations Range for the Detected Compunds in Analysed

\section{Matrices}

Surface waters (ng/L): Carbamazepine (4-40, max.

in Arges tributary); Sulfamethoxazole (2.5-30);

Diclofenac (4.8-166, max. in Arges tributary);

Ketoprofen (8.5-58, max. in Siret tributary);

Naproxen (6.1-22);

Piroxicam (3.7-32); Tylosine (11-39)

\section{5 compounds, including: macrolides,}

benzimidazole, tranquilizers, macrolides,

sulfonamides, quinolones, penicillins,

SPE-LC-HRMS Orbitrap MS-MS

tetracyclines, NSAIDs, antiepileptic, lipid regulator, coccidiostats targeted screening method
Surface waters (ng/L): Trimethoprim (>25);

Sulfamethoxazole $(>30)$; Diclofenac $(>50)$;

Carbamazepine (>20); Erythromycin (20-25)
Trimethoprim (3-12);

Surface waters (ng/L):Metformin (100-440; max. in

Jijia river); Acetamidantipyrine (75-210),

Gabapentin (<LOD-310, max. in Jijia river);

Propyphenazone (<LOQ-156);

Phenazone (15-73); Carbamazepine (7-14);
150 compounds, including various pharmaceuticals and metabolites
SPE-LC-HRMS-MS, full MS and DDA MS/MS
Carbamazepine-10,11-dihydro-10,11-dihydroxy
Diclofenac (<LOQ-150 max. in Jijia river); Caffeine (<LOQ-46); Atenol (LOQ-13); Atenolol acid (8.4-120); Fluconazole (6-24); Metoprolol (6-17);

Metronidazole (3.2-9); Sulfamethoxazole (2.1-61); Trimetoprim (2.4-11) 
Table 1. Cont.

\section{Sampling Site/Sampling Moment}

(Data)

Dniester River Basin (Ukraine and

Republic of Moldova)/May 2019
42 compounds, including: various pharmaceuticals and metabolites, drugs of abuse, stimulants
Relevant Environmental Concentrations Range for the Detected Compunds in Analysed

\section{Matrices}

Surface waters (ng/L): 4-Acetamidoantipyrine (6.34-1611); Carbamazepine (4.59-1981);

Carmabazepine metabolite (4.59-2858); Climbazole

(2.78-178); Fluconazole (61.3-3390); Ibuprofen

(51.5-155); Lamotrigene (16.2-189); Lidocaine

N-Oxide (0.7-7708); Metformin (1103);

Sulfamethoxazole (2.47-1229); Salicilic acid

(4.45-102); Trimethoprim (1-56); Norephedrine

(0.2-2633); Caffeine (24.1-1180)

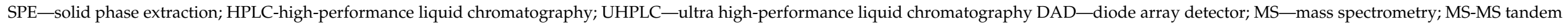

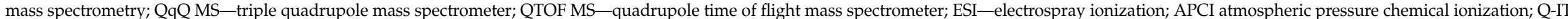

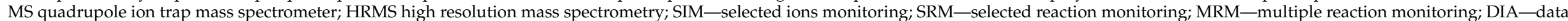
independent acquisition; DDA-data dependent acquisition. 
The selection of the monitored compounds in the listed studies (Table 1) was generally based on the occurrence in the aquatic environment, documented in previous reports or published data [10,39], frequency and magnitude of the pharmaceuticals usage [46], and updated priority substances [36,37].

Frequently monitored classes were: penicillins, macrolide and sulphonamides antibiotics, trimethoprim, antiepileptic carbamazepine, NSADs, lipid regulators, psychiatric drugs (benzodiazepines), diuretics, antidiabetics, etc.

More than 40 unregulated PhACs were reported in the listed publications (Table 1). Six studies reported the identification of metabolites for carbamazepine, aminophenazone, ibuprofen, metamizole, and others. The most reported antibiotic herein reviewed was sulfamethoxazole, followed by trimethoprim, and erythromycin. Among NSADs, the most reported was ibuprofen, followed by diclofenac. Substances found in fewer reports, but at very high concentrations were norephedrine ( $2633 \mathrm{ng} / \mathrm{L}$ in Dniester River), fluconazole (3390 ng/L in Dniester River) [26], and furosemide (444.63 ng/L in the Mures, River) [51].

Considering the studies on the Lower Danube River basin, the concentration of frequently monitored compounds in the surface water ranged as follows: carbamazepine 3.94-945 ng/L; diclofenac 0.8-255 ng/L; sulfamethoxazole 30-204 ng/L; trimethoprim 0.8-223 ng/L; ibuprofen 3.32-346 ng/L (Figure 2).

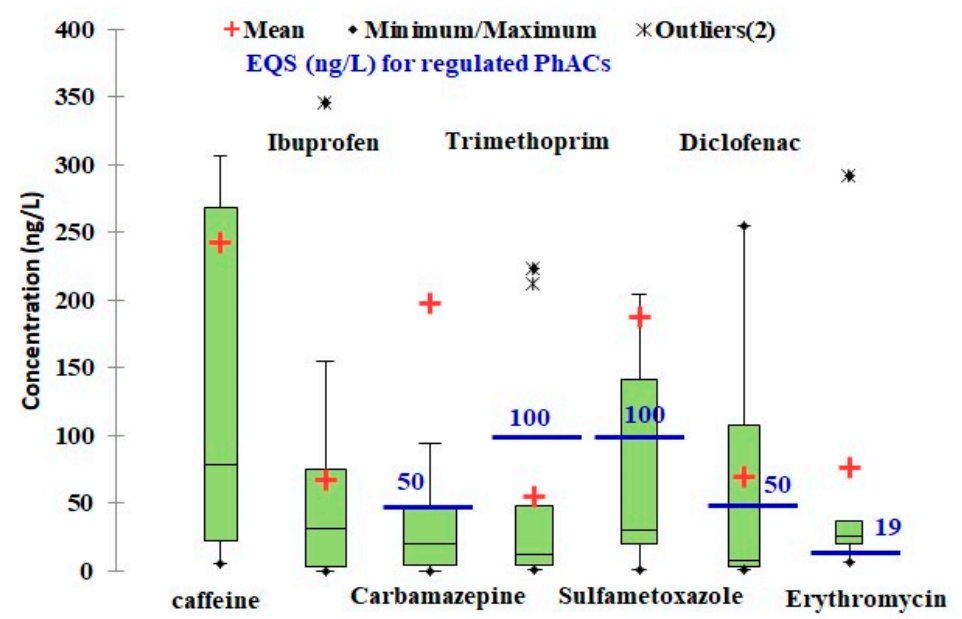

Figure 2. Variation of common pharmaceuticals in surface waters of Lower Danube basin compared to the proposed EQS, according to the Decisions 2018/840/EU and 2020/1161/EU.

Concentrations exceeding-EQS of carbamazepine, sulfamethoxazole, trimethoprim, diclofenac, and erythromycin were found in the Danube tributaries such as Morava river [38], Argeş river [10,44,49], Mureş river [51], and Jijia river [53], in sites that are heavily impacted by municipal or industrial wastewater discharges. Thus, the highest concentrations of carbamazepine ( $945 \mathrm{ng} / \mathrm{L})$, sulfamethoxazole (204 ng/L) and diclofenac ( $255 \mathrm{ng} / \mathrm{L}$ ) were reported in the Arges River, highly affected by the municipal and industrial discharges of the capital of Romania, the city of Bucharest. The concentration measured in the Danube River for the pharmaceuticals mentioned in the "Watch lists" [36,37] were below EQS.

Comparing with data on other river in Europe, including the upper Danube, concentrations of carbamazepine of 559 ng/L were reported in River Fyrisån (Sweden), 490 ng/L in river Grundlach (Germany), and $1670 \mathrm{ng} / \mathrm{L}$ in Ebro basin (Spain) [54]. High concentration of diclofenac of $930 \mathrm{ng} / \mathrm{L}$ was previously reported in upper Danube (Budapest, Hungary, September 2008) [55]. Sulfamethoxazole concentrations of $540 \mathrm{ng} / \mathrm{L}$ in surface water were recently reported in the upper Danube catchment area in Croatia [56].

However, the PhACs carbamazepine, diclofenac, and amoxicillin were previously listed as Danube basin-specific pollutants, derived within the EU-project SOLUTIONS [57]. 
Caffeine is also present in the Lower Danube and tributary waters. Both minimum (5.27 ng/L [47] and maximum concentrations (306 ng/L [46]) were reported along the Danube River near Novi Sad in two different studies. As this compound is efficiently removed by wastewater treatment plants, caffeine is a suitable marker of the presence of untreated wastewater. JDS3 reported a median concentration of caffeine of $93 \mathrm{ng} / \mathrm{L}$ in the Danube and $123 \mathrm{ng} / \mathrm{L}$ in the tributary [58].

Very high PhACs concentration was reported in the Dniester River (transboundary river between Ukraine and the Republic of Moldova) in a recent wide-scope screening study by Diamanti et al. [26]. In total, $40 \mathrm{PhACs}$ compounds and their metabolites were determined in surface water samples. The highest total cumulative PhACs concentration was $26.1 \mu \mathrm{g} / \mathrm{L}$ (a total of 35 contaminants) in a site receiving wastewaters from Chisinau town and the pharmaceutical industry. A concentration of carbamazepine of $1981 \mathrm{ng} / \mathrm{L}$ (more than double that the maximum concentration reported in Argeş River) and $2858 \mathrm{ng} / \mathrm{L}$ for carbamazepine metabolite was reported in Byk River, Moldova [26]. Fluconazole concentration of $3390 \mathrm{ng} / \mathrm{L}$ and sulfamethoxazole of $1290 \mathrm{ng} / \mathrm{L}$ were measured for the same sampling site. Additionally, metabolites such as 4-acetamidoantipyrine (maximum concentration of $1611 \mathrm{ng} / \mathrm{L})$ and 10,11-dihydro-10,11-dihydroxycarbamazepine (2858 ng/L) were detected in a higher concentration than the parent compounds [26], a fact that has been reported to occur in wastewater samples [51], and demonstrates the impact of uncontrolled discharge.

Compared to Dniester, in the transboundary Prut River (Romania and Moldova), 4-acetamidantipyrine ranged between 75-210 ng/L and 10,11-dihydro-10,11-dihydroxy carbamazepine from 16 to $40 \mathrm{ng} / \mathrm{L}$ [53].

Concentrations of PhACs in the river sediments were much lower than the ones found in surface water samples in all reported studies.

\subsection{Endocrine Disruptors (EDs)}

Due to androgenic or estrogenic activities even at low concentrations, endocrine disruptors (EDs) can induce adverse effects on endocrine systems related to alterations in endocrine function and sexual development or altered fertility and reproductive behavior for the aquatic wildlife [21]. Steroids estrogens, as the natural hormones estrone (E1), $17 \beta$-estradiol (E2), and estriol (E3), as well as the synthetic hormones $17 \alpha$-ethinyl estradiol (EE2) and diethylstilbestrol (DES), are of particular concern, being included in a European Union Water Framework Directive (WFD) "watch-list" [36]. EQS set levels of $0.4 \mathrm{ng} / \mathrm{L}$ for $\mathrm{E} 1$ and E2, and $0.035 \mathrm{ng} / \mathrm{L}$ for EE2, make their analysis extremely challenging.

Among steroids estrogens, bisphenol analogues (BPs), industrial chemicals mostly used as plasticizer, and alkylphenols nonylphenol (NP) and octylphenol (OP) formed by degradation of non-ionic surfactants were also identified as endocrine disrupters [59-61].

The presence of EDs in surface waters was reported from early 2001, in Germany rivers (including Danube) with concentrations ranging from 0.15 to $3.6 \mathrm{ng} / \mathrm{L} \mathrm{E} 2$ and 0.1 to $5.1 \mathrm{ng} / \mathrm{L}$ EE2 [62]. In 2003 in River Nene and River Lea (UK), concentrations of $0.9 \mathrm{ng} / \mathrm{L}$ mean E2 and $0.7 \mathrm{ng} / \mathrm{L}$ mean EE2 were reported [63] and in 2005 in Chesapeake Bay (SUA), in concentrations ranging from 1.9 to $6.0 \mathrm{ng} / \mathrm{L}$, for E2 and 0.1-17 ng/L for E1 was founded [64].

Among previously studies on the Danube River concerned EDs, a paper published in 2011 reported the presence of the contaminants in sediments samples from the Upper Danube River (Germany) [21]. EDs nonylphenol and bisphenol A (BPA), as well as the natural estrogen E1, were frequently detected in the concentration range of 6.5-1364 ng/g sediment equivalent (SEQ) for nonylphenol, 1.2-22 ng/g SEQ for bisphenol A and 0.019-0.24 ng/g SEQ for E1 [21]. The JDS3 reported the detection of E2 in surface water from eight sites, in a maximum concentration of $0.029 \mathrm{ng} / \mathrm{L}$ [58]. In a recent study on rivers of the Carpathian Basin, concentration ranges of $0.018-3.13 \mathrm{ng} / \mathrm{L}$ for E2 and 0.005-0.124 ng/L for EE2 were reported in the Danube River in Slovenia, and a maximum concentration of $0.45 \mathrm{ng} / \mathrm{L}$ for E2 was found in Tisza tributary [9]. 
Seven publications were identified concerning the presence of EDs in Low Danube basin waters, one in the Danube Delta and one in the Romanian Black Sea Coast area (Table 2). Surface water and sediments were analyzed within the listed studies. 
Table 2. Summary of the publication during 2010-2021 on the area of Low Danube and North-West Black Sea Basins concerning endocrine disruptors contaminants.

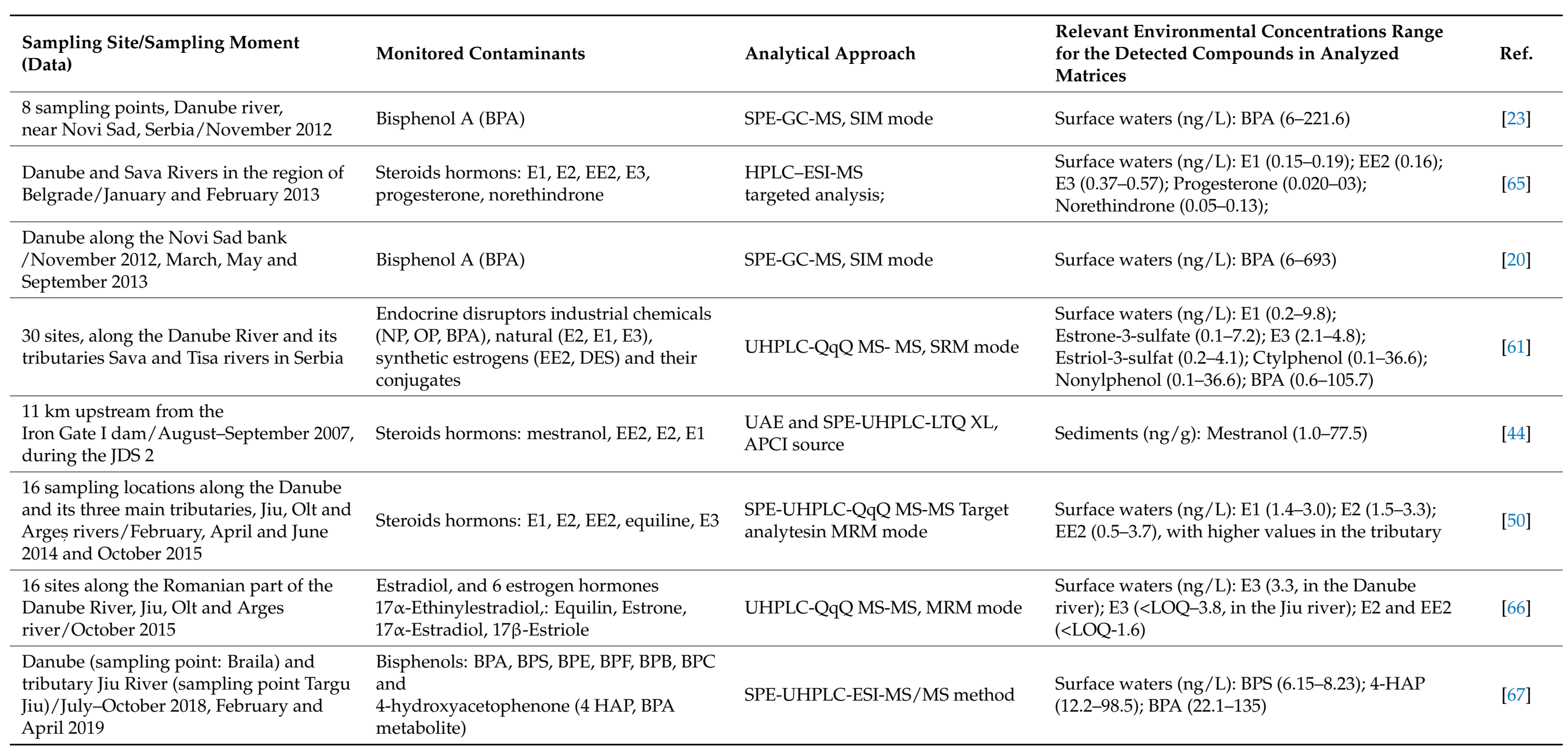


Table 2. Cont

\begin{tabular}{|c|c|c|c|c|}
\hline $\begin{array}{l}\text { Sampling Site/Sampling Moment } \\
\text { (Data) }\end{array}$ & Monitored Contaminants & Analytical Approach & $\begin{array}{l}\text { Relevant Environmental Concentrations Range } \\
\text { for the Detected Compounds in Analyzed } \\
\text { Matrices }\end{array}$ & Ref. \\
\hline $\begin{array}{l}11 \text { sampling points in the Danube } \\
\text { Delta/November } 2019\end{array}$ & $\begin{array}{l}\text { Bisphenols: BPA, BPS, BPE, BPF, BPB, BPC } \\
\text { and } 4 \text { HAP }\end{array}$ & $\begin{array}{l}\text { UHPLC-QqQ MS-MS targeted } \\
\text { analysis, SIM mode }\end{array}$ & $\begin{array}{l}\text { Surface waters (ng/L): BPA (4.2-9.02); BPE } \\
(<\text { LD-16.8);4-HAP (BPA metabolite) (3.56-30.9) }\end{array}$ & [68] \\
\hline $\begin{array}{l}45 \text { sites in the Romanian Black Sea Coast } \\
\text { area/August } 2020\end{array}$ & $\begin{array}{l}\text { Bisphenols: BPA, BPS, BPE, BPF, BPB and } \\
\text { BPC } \\
\text { 4-hydroxyacetophenone }\end{array}$ & UHPLC-QqQ MS-MS & $\begin{array}{l}\text { Seawater (ng/L): BPA(nd-416); BPF (nd-19.7); BPE } \\
\text { (nd-194) } \\
\text { Sediments (ng/g): BPC (3.8-16.2) } \\
\text { Algae (ng/g DW): BPA (nd-10.1); BPC (12-45); BPE } \\
\text { (nd-244); BPF(nd-53.9) }\end{array}$ & [69] \\
\hline
\end{tabular}

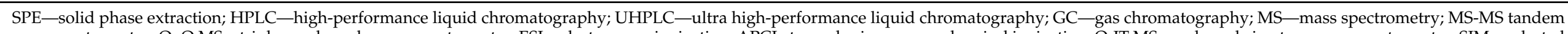

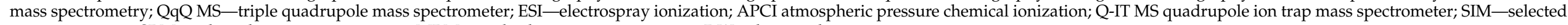
ions monitoring; SRM—selected reaction monitoring; MRM—-multiple reaction monitoring; DW—dry weight. 
Estrogenic hormones reported levels in the Lower Danube basin water ranged from 0.15 to $9.8 \mathrm{ng} / \mathrm{L}$ for E1 (with maximum value reported in Serbia [61]), from 1.5-3.3 ng/L for E2 (maximum value in the Argeş River [50]), from 0.37 to $4.8 \mathrm{ng} / \mathrm{L}$ for E3, and 0.5-3.8 ng/L for EE2 (with the maximum value in the Argeş River [50] (Figure 3, left side)). The values were higher than those reported by JDS3 [58], but comparable to other studies on European rivers $[9,70]$. Thus, concentration ranges of $0.17-7.3$ for E1 was reported in the Iberian River (Spain), of 2.4-4.0 ng/L in Tagus River (Portugal) and of 2.5-49 ng/L in Körsch river (Germany) [70]. EE2 concentration range of $0.47-2.2 \mathrm{ng} / \mathrm{L}$ was reported in the Tagus river (Portugal) [70].
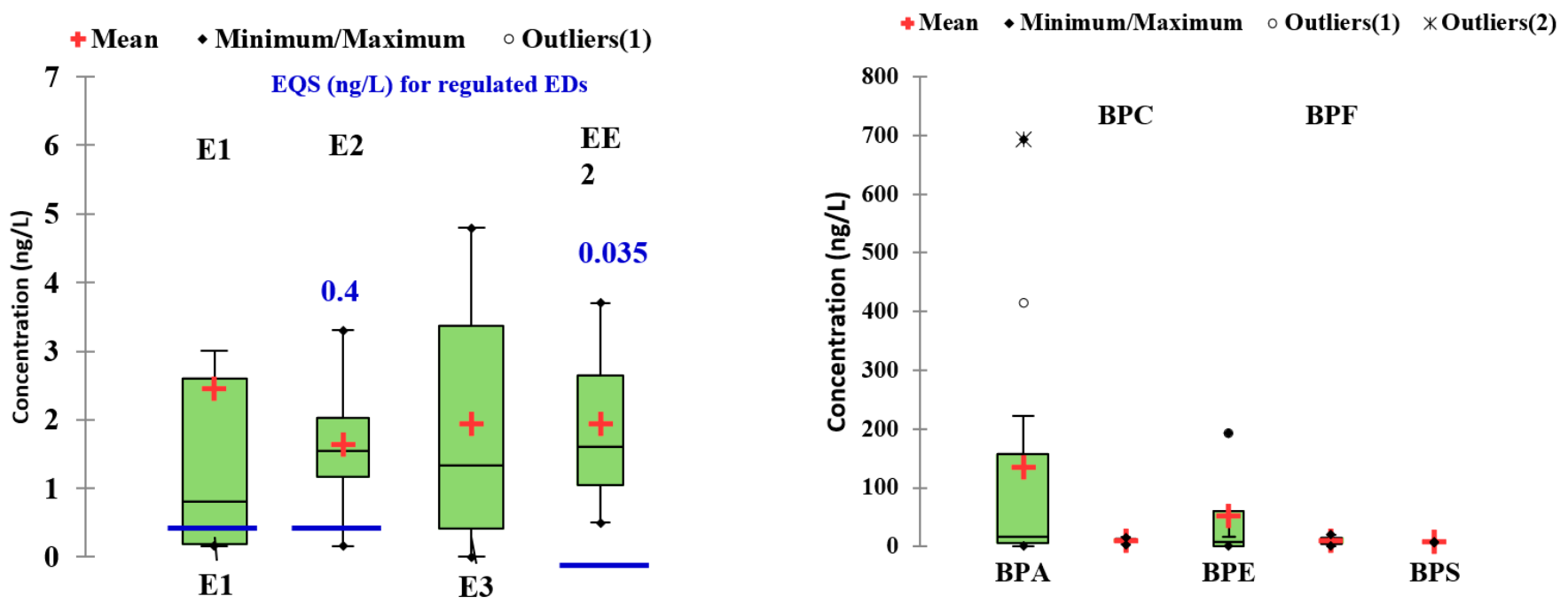

Figure 3. Variation of common EDs (left) and BPs (right) in surface waters of the Lower Danube basin. Proposed maximum acceptable concentration (MAC-EQS) for estrogen hormones according to the Decisions 2020/1161/EU are highlighted.

All four studies on the analysis of steroid hormones in surface water showed exceeding of the EQS for E1, E2 (0.4 ng/L), and EE2 $(0.035 \mathrm{ng} / \mathrm{L})$ both in the Danube $[50,65,66]$ and in tributaries Sava River [65], Tisa River [61], and rivers Olt, Jiu, and Argeş on Romanian territory $[50,66]$. However, measuring EE2 could be very challenging due to the maximum acceptable method detection limit of $0.035 \mathrm{ng} / \mathrm{L}$ imposed by the regulation [45]. Thus, among the four mentioned studies, two of them reported higher limits of quantification (LOQ) $[50,66]$.

Among bisphenol analogues, bisphenol A (BPA) is the most the most widespread in the aquatic environments. BPA was reported in five studies in the Low Danube basin including Delta and in one concerning the Romanian Black sea coast, in concentrations ranging from 0.6 to $693 \mathrm{ng} / \mathrm{L}$ (Figure 3, right side). Seasonal variation of Bisphenol A in the Danube river was studied by Milanović in 2015 [20]. Lower concentration levels were reported in winter (maximum $33 \mathrm{ng} / \mathrm{L}$, mean $6 \mathrm{ng} / \mathrm{L}$ ), while in the summer, a maximum concentration of $693 \mathrm{ng} / \mathrm{L}$ (mean $220 \mathrm{ng} / \mathrm{L}$ ) was registered due to an increase in the leaching of bisphenol A from plastic materials attributed to faster photo- and microbial degradation.

Significant lower concentrations were reported for other bisphenol analogues, such as $\mathrm{BPC}, \mathrm{BPE}$, and BPF.

One publication reported the presence of bisphenols in the sediment on the Romanian Black Sea coast. A maximum concentration of $416 \mathrm{ng} / \mathrm{L}$ BPA (with mean of $165 \mathrm{ng} / \mathrm{L}$ ) was measured in seawater and $10 \mathrm{ng} / \mathrm{L}$ (with of mean $6.3 \mathrm{ng} / \mathrm{L}$ ) in algae [69]. Although a high concentration was measured in seawater, a maximum of $0.8 \mathrm{ng} / \mathrm{L}$ was determined in sediment, which is much lower than other reported data.

By comparison, lower concentrations of bisphenol A have been reported in other marine environments around the world. Thus, BPA average concentration found in sediments sampled in the north of Adriatic Sea (Venice Lagoon) was $44.89 \mathrm{ng} / \mathrm{g}$, while those 
reported for the lagoons in Po River Delta of $18.64 \mathrm{ng} / \mathrm{g}$, and in the Kaštela Bay (Croatia) of $11.82 \mathrm{ng} / \mathrm{L}$ [71].

\subsection{Pesticides (Other Than Organochlorine)}

Pesticide is a broader term that covers herbicides, insecticides, nematicide, fungicides, plant growth regulator, defoliants, desiccants, and biocides. The pesticide pollution of surface waters or groundwater may have different pathways: surface run-off from farmyards, wastewater treatment plants, forestry, municipal use, grasslands and domestic gardens, or animal husbandry. Unlike pharmaceuticals, pesticides are designed to act against organisms (plants, insects) and have an inherent effect on the environment $[28,44]$.

In the European Union, the presence of pesticides in water is regulated through the Directive 2006/118/EC [72], which refers to groundwater, the Directive 98/83/EC [73] on the quality of water intended for human consumption, and the general Framework of Water Directive 2000/60/EC [74]. EU standard acceptable concentration for pesticides in ground water and drinking water is $0.1 \mu \mathrm{g} / \mathrm{L}$ [73].

Concerning the surface waters, Directive 2013/39/EU includes on a priority substances list several pesticides, among which are: triazine, organophosphorus pesticides, phenylurea pesticides (diuron, isoproturon), the pyrethroid cypermethrin, and various organochlorine pesticides, which are considered persistent organic pollutants (POPs) [35]. Recent Decision 2015/495/EU [75], Decision 2015/495/EU, 2018/840/EU [36], and Decision 2020/1161/EU [37] updated the previous regulations and several compounds such as azoles fungicides (e.g., imazalil, metconazole, miconazole, penconazole, prochloraz, tebuconazole), neonicotinoids (imidacloprid, thiacloprid, thiamethoxam, clothianidin, acetamiprid), triallate, and methiocarb were included on the "watch lists" with predicted no-effect concentration (PNEC) values set as maximum acceptable method detection limit and EQS.

Within the present research, seven studies on pesticides in the surface water samples, and sediment in the selected area were identified (Table 3). Target compounds selection was based on literature reporting the occurrence of the contaminants and the list of priority substances under the WFD [35]. Complex monitoring studies consider also the abiotic transformation products of such compounds, which in some cases may be more toxic, persistent, and bioaccumulative than the parent compounds (e.g., metolachlor-ESA, 2hydroxypropazine, 2-hydroxysimazine, desethylterbuthylazine) [26,45,53].

Among the detected compounds in the Lower Danube basin, relevant concentrations were reported for carbendazim (in a range of 0.6-269 ng/L), atrazine (4-392 ng/L), metolachlor (80-150 ng/L), dimethoate (7-23 ng/L), and imazalil (2.5-80 ng/L) (Figure 4). Griseofulvin was detected in the Danube Delta and Siret River [10]. Maximum concentrations were reported generally in tributary Tisa, Morava, and Siret River [10,39]. Higher concentration of dimethoate of $1222 \mathrm{ng} / \mathrm{g}$ was reported in Tisa River [39]. It is noteworthy that in the Dniester River, significantly higher concentrations than the Danube basin were reported, revealing the influence of untreated waters [26]. Thus, the concentrations of $4612 \mathrm{ng} / \mathrm{L}$ for metolachlor and $107 \mathrm{ng} / \mathrm{L}$ for imidacloprin recorded in the Prut River are over 30 times higher than the maximum concentrations in the Danube basin. Terbuthylazine maximum concentration of $2514 \mathrm{ng} / \mathrm{L}$ in the Dniester River is also significantly higher relative to those reported in the Danube (of $200 \mathrm{ng} / \mathrm{L}$ ) and in the Prut river (of $41.4 \mathrm{ng} / \mathrm{L}$ ). Concentration of carbandazim (of $755 \mathrm{ng} / \mathrm{L}$ ) was almost three times higher than that reported for the Danube. A maximum concentration of diuron of $1197 \mathrm{ng} / \mathrm{L}$ was measured in the central part of Dniester basin (Moldova) [26]. For comparison reasons, worth mentioning are the maximum concentrations of imazalil of $409.73 \mathrm{ng} / \mathrm{L}$ and diuron of $150 \mathrm{ng} / \mathrm{L}$ measured in the Ebro River basin (Spain) [76]. 
Table 3. Summary of the publication during 2010-2021 on the area of Low Danube and Nord-West Black Sea Basins concerning pesticides (other than organochlorine).

\section{Sampling Site/Sampling Moment (Data)}

Two sampling points on the Danube River (Novi Sad and Kovin, Serbia) and three sampling sites from tributaries: the Tisa River, the Sava River, the Morava River/Not mentioned

16 sampling sites on the Danube river including also major tributary Sava, Morava and Tisa/June and October of 2009, February, April, May, June, September, October of 2010, and June and September of 2011.

SPE-LC-MS/MS and GC-MS

SPE LC-QqQ quadrupole ion trap mass spectrometer, SRM mode

Iron Gate I Reservoir on the Danube River/ August-September 2007, JDS2

UAE and SPE-LC-ion trap LTQ ESI

Middle and low of the Danube River and its tributaries / August to September 201 (JDS3)

16 samples from Danube river and from three of the main affluents: Siret, Olt, Arges; 4 samples from Danube Delta/ May, June, August, and October 2014

Three sampling campaigns along the 250-km-long stretch of the Prut River/May and November 2011, and June 2012

GC-MS SIM mode

SPE-LC-HR Orbitrap MS-MS, Targeted analysis in SIM mode

SPE-GC-MS

SPE-LC-HRMS, full MS and DDA MS/MS

Dniester River Basin (Ukraine and Republic of Moldova)/May 2019

\section{LC-ESI-QTOF-HRMS in DIA and DDA acquisition modes}

Relevant Environmental Concentrations Range for the Detected Compounds in Analyzed Matrices

Ref.

Sediments (ng/g): Dimethoate (79-1222 in Tisa river); Carbofuran (7-21 in sediment in Morava river); Propazine (8-72 in sediment in Morava river)

Ground water ng/L): Carbendazim (3-88 in, Danube); Surface waters (ng/L): Atrazine (4-392 in Morava river); Malathion (67-69 in Morava river)

Surface waters (ng/L): Carbendazim (8-269 in Morava river); Atrazine (20-188 in Morava river); Terbuthylazine(130-200 in the Danube river); Acetochlor (40-110 in Morava river); Metolachlor (80-150 in the Danube); Dimethoate (7-23 in the Danube); Propazine (8-18 in Morava river)

Sediments (ng/g): Carbendazim (0.6-2.4); Imidacloprid(0.8-3.5); Carbofunan (0.3-3.2); Atrazine (0.4-5.8); Propazine (0.3-1.7); Linuron (2.2-8.7); Malathion (1.4-2.9)

Surface waters (ng/L): Tris(2-chloroethyl)-phosphate TCEP (41 in Iskar River); Metolachlor (39) 2,4-D (22)

Surface waters (ng/L): Enilconazole (2.5-80 in the Danube);

Griseofulvin (2.1-57 in the Danube Delta); Carbendazim (6-30 in the Arges river); Thiabendazole (ND-53 in the Danube); Metalaxil (65 in the Siret river)

Surface waters (ng/L): Bentazone (9.1-65); Atrazine (5.1-9.5);

Terbutlyazine (ND-41, 4); Acetochlor (ND-28); Metalachlor(ND-33); 4-phenylbenzo-phenone (ND-323); 2,4 D (5.4-8.9) Surface waters (ng/L): Acetochlor (<28.6-238); Atrazine $(<7.82-55.2)$; Carbaryl $(<55.8-1353)$ Carbendazim $(<7.1-755) ; 2$-aminobenzimidazole (<5.39-311); Dimethenamid (<0.84-1189); Dimethoate $(<9.13-85.2)$; Diuron (<10.9-1197); Imidacloprid (<14.6-107); Metolachlor

(<3.41-4612); Nicosulfuron (<2.24-32.5); 2, 4, D amine (5.4-8.9); Simazine (70.4-2010); Tebuconazole (3.3-11.2); Maximum values, were reported in the central part of the basin, Moldova theritory

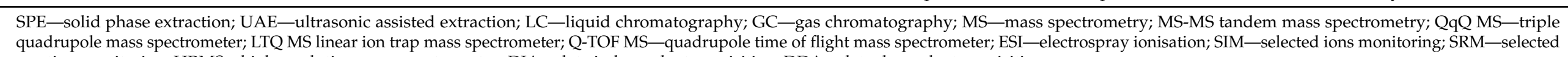
reaction monitoring; HRMS - high resolution mass spectrometry; DIA—-data independent acquisition; DDA—data dependent acquisition. 


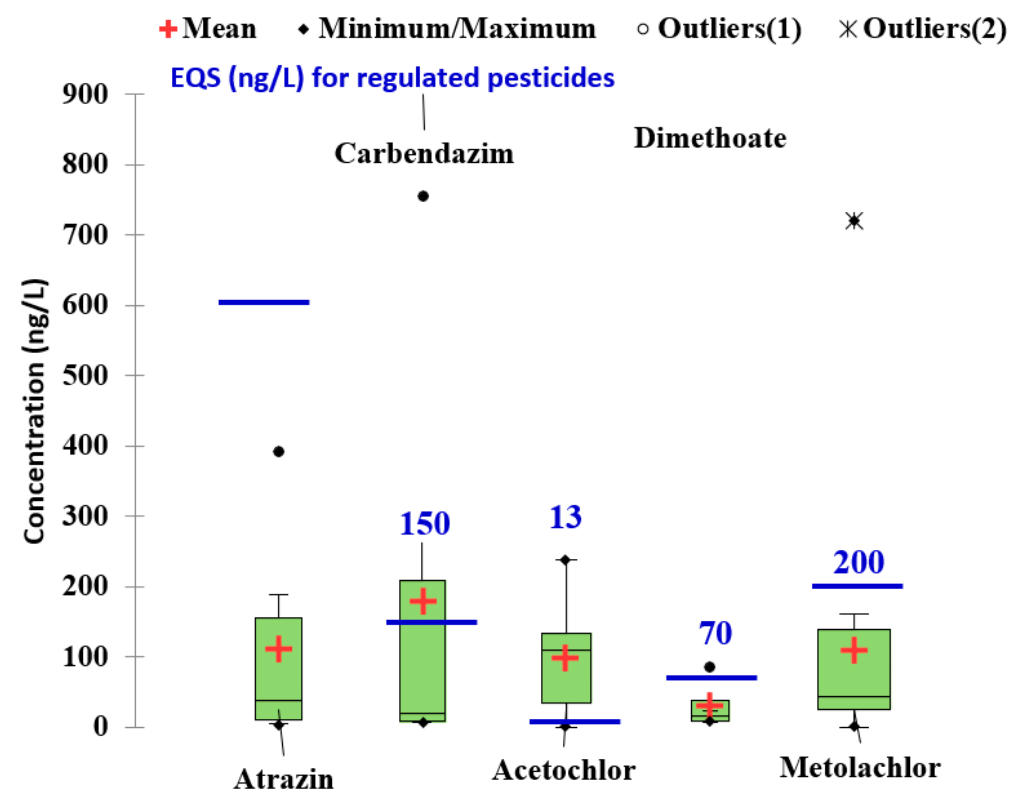

Figure 4. Variation of common pesticides in surface waters of Lower Danube basin compared to the PNEC values, according to the NORMAN Prioritization Framework.

In the Danube River basin, PNEC has been exceeded for carbendazim [77] and dimethoate [39]. In the Dniester River the value of PNEC was exceeded for acetochlor, carbaryl, dimethoate, diuron, imidacloprid, omethoate, metolachlor, terbuthylazine [26]. Most papers describe point surveys or seasonal monitoring, except the multi-year study of Antic' et al. [77], in which variations in concentration of pesticides as carbendazim, propazine, and dimethoate were attributed to their seasonal application during spring and to the rainfall above normal, leading to increased runoff.

\subsection{Personal Care Products (PCPs)}

This large category of emergent contaminants includes chemicals found in consumer products such as cosmetics, fragrances, disinfectants, antiseptics, UV filters, and insect repellents. Among the reviewed papers, fewer included PCPs monitoring.

Triclosan and triclocarban, highly used disinfectants in personal care products, were measured in surface water in 16 sites along the Romanian side of the Danube and its three main tributaries, Jiu, Olt, and Arges rivers in 2014 in a range of $0.7-18.4 \mathrm{ng} / \mathrm{L}$ for triclorsan and $0.6-54 \mathrm{ng} / \mathrm{L}$ for triclocarban [50]. In a recent study on the Prut river, triclosan was reported in a range of $12.5-159 \mathrm{ng} / \mathrm{L}$ [26].

The occurrence of the 10 organic UV-filters on the North-Western Black Sea coast was reported for the first time in 2020 by Chiriac et al. [69]. High levels up to $5607 \mathrm{ng} / \mathrm{L}$ of BP3 (2 hydroxy-4-methoxy-benzophenone) were measured in the seawater. 234HBP (2,3,4-trihydroxybenzophenone) reached a maximum level of $824 \mathrm{ng} / \mathrm{L}$ and BP1 (2,4tdihydroxybenzophenone) of $600 \mathrm{ng} / \mathrm{L}$ in seawater. Salicylate derivatives (ethylhexyl salycilate and homosalate) were also detected in high concentrations of $1286 \mathrm{ng} / \mathrm{L}$ and, respectively, $1262 \mathrm{ng} / \mathrm{L}$ in seawater, but reached a maximum value of $5823 \mathrm{ng} / \mathrm{L}$ of ethylhexy salicylate in sediments.

Insect repellent DEET (N,N-Diethyl-meta-toluamide) was monitored along the Danube River and its tributaries within JDS3. In the Lower Danube waters, the measured levels were lower than $10 \mathrm{ng} / \mathrm{L}$, while maximum levels in the Morava (81 ng/L) and Arges (37 ng/L) tributaries were reported [44]. In the Dniester River basin, a maximum concentration of $345 \mathrm{ng} / \mathrm{L}$ was reported [26]. 


\subsection{Other CECS}

Among perfluorinated acids (PFAs), PFOS (perfluorooctanesulfonic acid) concentration at the Danube river mouth in Romania in 2007 was of $6 \mathrm{ng} / \mathrm{L}$ and PFOA (perfluorooctanoic acid) of $12 \mathrm{ng} / \mathrm{L}$ (reported within JDS2) [45]. Higher PFOS concentration levels were detected in tributaries: Morava (20 ng/L), Jantra (57 ng/L), and Arges (101 ng/L) [49]. Discharge levels of PFOA at the river mouth in Romania fell to $5 \mathrm{ng} / \mathrm{L}$ in 2013 (JDS3) [45].

Low PFOA levels ranging from 0.6-1.0 ng/g were reported in 2019 in sediment core from the Iron Gate I Reservoir, the largest impoundment on the Danube River, at the boundary between Serbia and Romania. [44].

Different concentrations of 1H-benzotriazole were measured during JDS3 in the tributary Tisa $61 \mathrm{ng} / \mathrm{L}$, Sava $63 \mathrm{ng} / \mathrm{L}$, Velika Morava $135 \mathrm{ng} / \mathrm{L}$, Timok $2 \mathrm{ng} / \mathrm{L}$, Iskar $161 \mathrm{ng} / \mathrm{L}$, Olt 39 ng/L, Jantra 24 ng/L, Siret 27 ng/L, and Prut 7 ng/L [45]. 5-Methyl-1H-benzotriazole was reported with a higher concentration, of $110 \mathrm{ng} / \mathrm{L}$, in Prut river in 2018 [53].

Artificial sweeteners acesulfame, cyclamate, and saccharin were detected in Moldovan tributary Prut river in concentrations ranging from 120 to $2000 \mathrm{ng} / \mathrm{L}, 18-110 \mathrm{ng} / \mathrm{L}$, and 36-49 ng/L, respectively [53].

The most frequently reported contaminants of emerging concern in the study area for the target period of time were: pharmaceuticals (carbamazepine, sulfamethoxazole, and diclofenac, trimethoprim, and caffeine), bisphenol A, estrogens, caffeine, pesticide (atrazine, carbendazim, metolachlor), and PCP-like triclosan (Figure 5). 


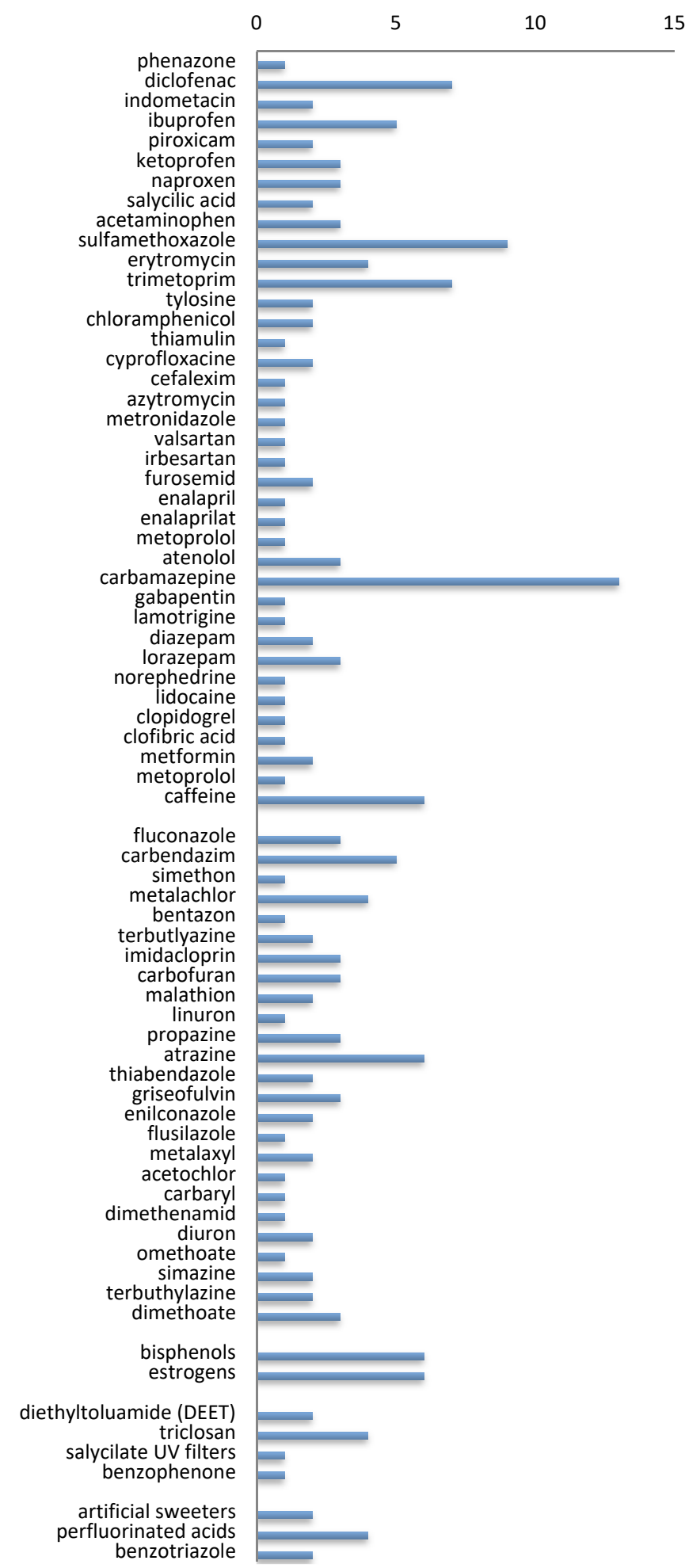

Figure 5. Frequency of the detection of certain CECs reported in the monitoring campaigns on Lower Danube and North-Western Black Sea basins, published between 2010 and 2021.

\section{Persistent Organic Pollutants}

Persistent organic pollutants (POPs) are non-polar organic compounds with high stability and high bioaccumulation properties, toxic at threshold level [78]. The potentially most-hazardous POPs include: industrial by-products dioxins and dibenzofurans, organochlorinated pesticides (OCPs) (dichlorodiphenyltrichloroethane and its four isomers (DDTs), hexachlorocyclohexanes (HCHs), aldrin, dieldrin, endrin, chlordane, hep- 
tachlor, toxaphene, mirex, hexachlorobenzene) and chemicals resulting from industrial processes such as polychlorobiphenyls (PCBs), brominated flame retardants (BFRs), and polycyclic aromatic hydrocarbons (PAHs). POPs fall under incidence of the Stockholm Convention [79], Water Framework Directive 2000/60/EU [74], Commission Regulation 850/2004/CE [78], and Directive 2008/105/EC [80]. Environmental quality standards (EQSs) concerning the presence in surface water of the priority pollutants are set. Of the hundreds of known PAHs, 16 have been designated High Priority Pollutants by the United States Environmental Protection Agency (US EPA) [81] and are consistently monitored in the water bodies and reported as $\Sigma 16$ PAHs (US EPA PAHs). Similar, a set of six indicator PCBs (indicator $\Sigma 6$ PCBs) was recommended by the EU for assessing the pollution by PCBs [82].

Due to high hydrophobic nature and low solubility in water, POPs can be adsorbed on sediment particles or water-suspended particles, leading to the accumulation and concentration in different compartments of the aquatic ecosystems (water, sediment, biota) [2] International standardized methods are available for the quantification of POPs in surface water or sediments [43]. Solid phase microextraction and liquid-liquid or solid-liquid extractions are the methods employed for the sample processing phase. Due to the complexity of the POPs' nature, multi-methods allowing detection and quantification of a large number of contaminants, such as gas chromatography-mass spectrometry (GC-MS) or gas chromatography coupled with an electron capture detector (GC-ECD), are generally used in the monitoring programs.

During 2010-2021, 16 studies were identified on POPs for the selected area (Table 4). Among POPs, PAHs were investigated in 10 studies, PCBs in 5, and OPCs in 11. Most studies were focused on the analysis of sediment or top soil (12 publications) and surface water (four studies). Although POPs analysis in aquatic organisms' tissues is highly relevant for the assessment of the water ecosystem pollution [2], only two studies considered fish as matrix. Previously investigation of highly persistent PCBs and DDTs in fish from Danube River and the Black Sea were performed by Covaci, (2006) [2] and Stoichev, (2007) [83].

Most of the reviewed studies describe complex monitoring programs over several years [84-86]. The Danube Delta was investigated in 2 publications, the Black Sea in 4, the Dniester basin in 1, and the Danube basin in 11. Data systematized in Table 4 show values for total concentrations of $\Sigma 16 \mathrm{PAHs}$ in sediment ranging from 70 to $6983 \mu \mathrm{g} / \mathrm{kg}$, for $\Sigma$ PCBs from $0.3-74 \mu \mathrm{g} / \mathrm{kg}$ and for $\Sigma \mathrm{DDTs}$ from 0.7 to $61.7 \mu \mathrm{g} / \mathrm{kg}$ (Figure 6). Compared with other data on river sediments in Europe, including the upper Danube, the concentrations of $\Sigma 16$ PAHs (US EPA PAHs) in the sediment samples from the Lower Danube basin were higher than those reported for Danube in Hungary $(8.3-1202 \mu \mathrm{g} / \mathrm{kg}$ ) [87], Tiber River in Italy $(157.8-271.6 \mu \mathrm{g} / \mathrm{kg})$ [88], or from Durance River in France $(57-1527 \mu \mathrm{g} / \mathrm{kg})$ [89], but lower than those reported in the Ammer River in Germany $(112-22,900 \mu \mathrm{g} / \mathrm{kg})$ [90] and Ría de Arousa in Spain (45-7901 $\mu \mathrm{g} / \mathrm{kg}$ dry wt.) [91].

Data of PCB in sediments and fishes collected in the Danube Delta in 2001 have been reported [2]. In sediments, $\Sigma$ PCBs $<2 \mu \mathrm{g} / \mathrm{kg}$ and $\Sigma$ DDTs in the range $0.9-17 \mu \mathrm{g} / \mathrm{kg}$ were found. Compared with this, more recent data on sample collected in 2009-2011 show a dramatic increase in $\Sigma 6 \mathrm{PCBs}$ level ranging from 27.3 to $74 \mu \mathrm{g} / \mathrm{kg}$ and $\Sigma$ 3DDTs from 0.4 to $29.1 \mu \mathrm{g} / \mathrm{kg}[92]$. 
Table 4. Summary of the publications during 2010-2021 on the area of Low Danube and North-West Black Sea Basins concerning POPs.




Table 4. Cont

\begin{tabular}{|c|c|c|c|c|}
\hline Sampling Site/Sampling Moment (Data) & Monitored Contaminants & Analytical Approach & $\begin{array}{l}\text { Relevant Environmental Concentrations Range for the } \\
\text { Detected Compounds in Analyzed Matrices }\end{array}$ & Ref. \\
\hline $\begin{array}{l}50 \text { sites in Low Danube basin and Dniester } \\
\text { basin, Romania and Republic of } \\
\text { Moldova/2011 }\end{array}$ & OCPs, PAHs & $\begin{array}{l}\text { GC withECD for OPCs (SMV ISO } \\
\text { 10382:2008) } \\
\text { GC-MS for PAHs, SIM mode }\end{array}$ & $\begin{array}{l}\text { Top soil }(\mu \mathrm{g} / \mathrm{kg}) \text { : Chlordane }(0.28-1084.3) \text {; Toxaphene } \\
\text { (5.2-3901.2); Heptachlor }(1.2-505) ; \text { total triazine }(<1-250) \text {; } \\
\text { Trifuraline }(<1-250) \text {; } \\
\Sigma \text { HCHs }(0.17-2101,20) ; \Sigma D D T s \text { max: } 3148 ; \Sigma 17 \text { PAHs max: } \\
367,0\end{array}$ & [101] \\
\hline $\begin{array}{l}\text { Saint George branch, } \\
\text { the Danube Delta/February 2009-February } \\
\text { 2011, monthly monitoring }\end{array}$ & PAHs, PCBs, OCPs & $\begin{array}{l}\text { HPLC andGC with ECD (OPCs and } \\
\text { PCBs) }\end{array}$ & $\begin{array}{l}\text { Surface waters }(\mu \mathrm{g} / \mathrm{L}) \text { : DDT (max. of } 0.649) ; \Sigma 6 \mathrm{PCBs} \\
(0.003-0.013) \\
\text { Sediments }(\mu \mathrm{g} / \mathrm{kg}): \alpha-\mathrm{HCH}(0.2-11.0) ; \beta-\mathrm{HCH}(0.3-22.0) ; \\
\delta \text {-HCH }(0.3-8.0) ; \mathrm{Heptachlor}(0.7-8.0) ; \text { Endrin }(0.3-11) ; \\
\text { Lindane }(0.2-45.0) ; \\
\Sigma 6 \mathrm{PCBs}(27.3-74, \text { maximum value of } 415 \text { in a sampling } \\
\text { site near ships pontoon); } \Sigma \text { 3DDTs }(0.4-29.1) ; \Sigma 16 \text { PAHs } \\
(100-24570)\end{array}$ & [92] \\
\hline $\begin{array}{l}\text { Danube River } \\
\text { Bulgarian Black Sea coast } 2010\end{array}$ & $\begin{array}{l}14 \text { PCBs, DDT and its metabolites } \\
\text { DDE and DDD }\end{array}$ & $\begin{array}{l}\text { GC-Ion Trap MS } \\
\text { Method US EPA 1668a }\end{array}$ & $\begin{array}{l}\text { Freshwater fish }(\mu \mathrm{g} / \mathrm{kg} \mathrm{WW}): \Sigma \text { PCBs }(0.0062-0.0125) \\
\Sigma 6 \mathrm{PCBs}(0.0052-0.0097) ; \Sigma 3 D D T s(0.0192-0.03028) \\
\text { Sea fish }(\mu \mathrm{g} / \mathrm{kg} \text { WW }) \Sigma \text { PCBs }(0.0059-0.0478) ; \\
\Sigma 6 \text { PCBs }(0.0051-0.0346) ; \Sigma \text { 3DDTs }(0.0541-0.217)\end{array}$ & [86] \\
\hline Bulgarian Black Sea coast/2007-2011 & OPCs (DDT, DDE and DDD) & GC-MS & Fish $(\mu \mathrm{g} / \mathrm{kg} \mathrm{WW}):$ S3DDTs $(0.0185-0.200 \mathrm{ww})$ & [86] \\
\hline $\begin{array}{l}12 \text { sampling sites marine areas of the } \\
\text { Romanian Black Sea sector/2011-2012 }\end{array}$ & 16 PAHs & GC-MS & Sediments $(\mu \mathrm{g} / \mathrm{kg}): \Sigma 16$ PAHs $(82-6,983)$ & [102] \\
\hline $\begin{array}{l}\text { Romanian part of theBlack Sea/March 2010, } \\
\text { May 2011, March-April } 2012 \text { October } 2012 \\
\text { Ukrainian marine waters near Zmeiny Island, } \\
\text { 2010Danube Delta; Danube estuarine } \\
\text { coast/2010-2011 }\end{array}$ & 16 PAHs & GC-MS & $\begin{array}{l}\text { Surface water }(\mu \mathrm{g} / \mathrm{L}): \Sigma 16 \text { PAHs }(0.071-1.146 \text { in } 2010, \\
0.190-2.3222011 \text { and } 1.683-28.976 \text { in } 2012) \\
\Sigma 16 \text { PAHs }(0.649-0.748 \text { in } 2010) \\
\text { Sediments }(\mu \mathrm{g} / \mathrm{kg}) \text { : } \\
\Sigma 16 \text { PAHs } 602.2-1346 \text { in } 2010,321-3045 \text { in } 2011 \text { and } \\
304-5611 \text { in } 2012) \\
\text { Sediments }(\mu \mathrm{g} / \mathrm{kg}): \Sigma 16 \text { PAHs }(329-1093 \text { in } 2010 \text {; and } \\
293.8-1001 \text { in } 2011) \\
\text { Sediments }(\mu \mathrm{g} / \mathrm{kg}): \Sigma \text { 16PAHs (329-1093) }\end{array}$ & [103] \\
\hline
\end{tabular}

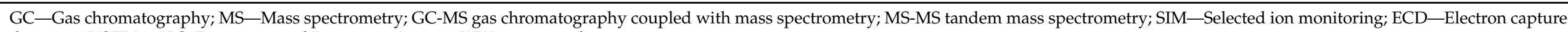
detection; USEPA-U.S. Environmental Protection Agency; WW—wet weight. 

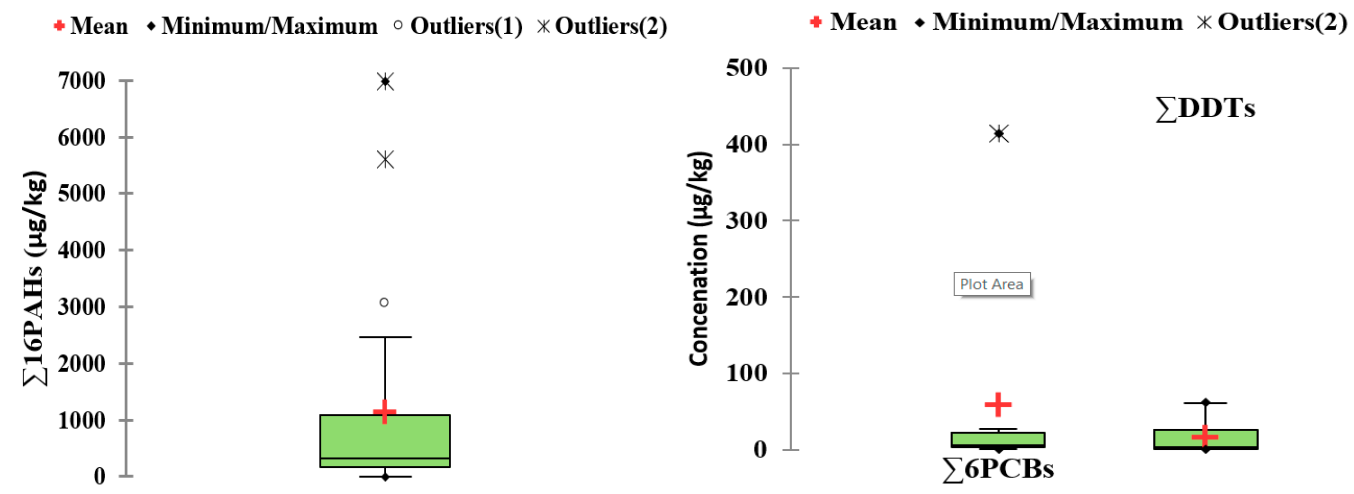

Figure 6. Variation of sum of the 16 PAHs, 6 PCBs and DDTs in the Lower Danube basin.

The Black Sea state of the environment report, published in 2019 by the Commission on the Protection of the Black Sea Against Pollution [103], revealed total concentrations of 16 EPA PAHs in sediment in the Danube Delta ranging from 329-1093 $\mu \mathrm{g} / \mathrm{kg}$ for samples collected in 2010-2011. A much higher maximum concentration of $24570 \mu \mathrm{g} / \mathrm{kg}$ was reported by another study for a sampling site in Murighiol near the pontoon of the supply ship. A maximum value of $414 \mu \mathrm{g} / \mathrm{kg}$ for $\Sigma \mathrm{PCBs}$ was reported in the same sapling point (Danube Delta, Murighiol, near the pontoon of the supply ship) [92].

Concentrations of PAHs ranging from 12.2 to $260 \mathrm{ng} / \mathrm{L}$ [96] and of PCBs from 3 to $13 \mathrm{ng} / \mathrm{L}$ in Lower Danube basin waters were reported (Figure 6). Much lower values of PAHs in water (5-72 ng/L) and of PCBs (0.005 to $0.016 \mathrm{ng} / \mathrm{L}$ ) were reported for the middle stretch of the Danube river between the cities of Vienna and Bratislava [104]. Overall, data suggest a considerable increasing of the organic pollution in the Danube Delta area.

However, regarding the data in Table 4 , it is difficult to draw a conclusion due to the heterogeneity of the studies. For example, while the data provided by studies on PAH pollution in the Black Sea coastal area are comparable (a range of 82-6983 $\mu \mathrm{g} / \mathrm{kg}$ was reported by Tुigănuş et al. [102] and of 304-5611 $\mu \mathrm{g} / \mathrm{kg}$ by "The Black Sea state of the environment" report [103]), for the Prut and Dniester rivers, no comparison can be made because the analyzed matrix is different (topsoil and river sediments). The same, in the Danube Delta, a values range of 329-1093 $\mu \mathrm{g} / \mathrm{kg}$ was reported for $\Sigma$ 16PAHs in sediment by "The Black Sea state of the environment" report [103], while Vosniakos et al. outlined only a maximum value of $24570 \mu \mathrm{g} / \mathrm{kg}$ for $\Sigma 12 \mathrm{PAHs}$ corresponding to a sampling site near the supply ships pontoon [92]. No comparisons can be made neither for the values of $\Sigma 16 \mathrm{PAHs}$ or $\Sigma 6$ PCBs in Danube River sediment. Škrbic 's et al. study reported values includes tributary, where larger amounts of pollutants are usually found [95], while Radu's et al. study does not [84]. In terms of PCBs, Brborić et al. reported the sum of seven PCB congeners [94] while Radu et al. reported only 6six of them [84].

\section{Metals}

Heavy metals pollution is a significant environmental hazard for invertebrates, fish, and humans due to their toxicity, persistence, and bioaccumulative nature [104,105]. Their natural sources include corrosion of the metal-containing rocks, soil erosion, and volcanic eruptions, while principal anthropogenic sources include industrial emissions, mining, smelting, foundries, and agricultural activities using pesticides, insecticides, and fertilizers [105]. While, naturally, trace elements in sediments are mainly associated with silicates, anthropogenic pollution leads to the release into the environment of more mobile and reactive elements [106]. Environmentally relevant heavy metals and metalloids include $\mathrm{Cr}, \mathrm{Ni}, \mathrm{Cu}, \mathrm{Zn}, \mathrm{Cd}, \mathrm{Pb}, \mathrm{Hg}$, and $\mathrm{As}$ [107]. As the studies on the metal content are more numerous compared with those on other pollutants, for the present review a selection of 
28 representative studies was carried out in terms of area, matrix, and analyzed elements (Table 5).

Among the selected studies, 17 studies concerned the Lower Danube basin in Serbia, Bulgaria, Romania, and Republic of Moldova, 6 studies-the Danube Delta, 4 studies-the Black Sea coasts (in Romania and Bulgaria), and 2-the Dniester River (Ukraine). 
Table 5. Summary of selected publications during 2010-2021 on metal pollution in the area of Low Danube and North-West Black Sea Basins.

\begin{tabular}{|c|c|c|c|c|}
\hline Sampling Site/Sampling Moment (Data) & Monitored Contaminants & Analytical Approach & $\begin{array}{l}\text { Relevant Environmental Concentrations Range for } \\
\text { the Detected Compounds in Analysed Matrices }\end{array}$ & Ref. \\
\hline $\begin{array}{l}\text { Belgrade section of the Danube River (from } \\
\text { 1168th to 1170th river km), } \\
\text { Serbia/October-November } 2010\end{array}$ & $\begin{array}{l}\text { As, B, Ba, Cd, Co, Cr, Cu, Fe, } \mathrm{Hg}, \mathrm{Li}, \mathrm{Mn}, \\
\mathrm{Mo}, \mathrm{Ni}, \mathrm{Pb}, \mathrm{Se}, \mathrm{Sr} \text {, and } \mathrm{Zn}\end{array}$ & (ICP-OES & $\begin{array}{l}\text { Surface waters ( } \mu \mathrm{g} / \mathrm{L}): \mathrm{Al}(17-18) ; \mathrm{As}(1.1-1.6) ; \mathrm{Cd} \\
(0.03-0.18) ; \mathrm{Cu}(2.8-10.1) ; \mathrm{Fe}(120-380) ; \mathrm{Mn}(\mathrm{ND}-20) ; \mathrm{Zn} \\
(3.8-10.5) \\
\text { Fish muscle (mg/kg DW): } \\
\mathrm{Al}(4.87-7.56) ; \mathrm{As}(0.17-0.93) ; \mathrm{Cd}(0.005-0.01) ; \mathrm{Ba} \\
(0.66-2.18) ; \mathrm{Cr}(0.01-0.08) ; \mathrm{Mn}(0.12-0.87) ; \mathrm{Cu}(0.75-1.42) ; \\
\mathrm{Hg}(0.89-1.63) ; \mathrm{Zn}(15.14-59.01)\end{array}$ & [108] \\
\hline $\begin{array}{l}\text { Danube and tributary on Serbian } \\
\text { territory/ } 2011 \text { and } 2013 \text {, } \\
\text { during the same season (June-October) }\end{array}$ & $\begin{array}{l}\mathrm{Al}, \mathrm{As}, \mathrm{Cd}, \mathrm{Co}, \mathrm{Cr}, \mathrm{Cu}, \mathrm{Fe}, \mathrm{Hg}, \mathrm{Mn}, \mathrm{Ni} \\
\mathrm{Pb} \text {, and } \mathrm{Zn}\end{array}$ & ICP-OES & $\begin{array}{l}\text { Surface Waters ( } \mu \mathrm{g} / \mathrm{L}) \text { : } \mathrm{Al}(80-470) ; \mathrm{As}(0.5-5) ; \mathrm{Cd} \\
(0.1-50) ; \mathrm{Cr}(0.5-90) ; \mathrm{Cu}(5-70) ; \mathrm{Fe}(810-8140) ; \mathrm{Hg}(0.1) ; \\
\mathrm{Mn}(10-180) ; \mathrm{Ni}(0.9-220) ; \mathrm{Pb}(0.3-10) ; \mathrm{Zn}(6-340) \\
\text { Fish (mg/kg WW): } \mathrm{Al}(0.07-0.93) ; \mathrm{As}(0.09-0.4) ; \mathrm{Cd} \\
(0.001-0.09) ; \mathrm{Cr}(0.1-1.41) ; \mathrm{Cu}(0.07-2.78) ; \mathrm{Fe}(0.81-8.14) ; \\
\mathrm{Hg}(0.004-0.78) ; \mathrm{Mn}(0.08-0.41) ; \mathrm{Ni}(0.009-0.07) ; \mathrm{Pb} \\
(0.11-0.82)\end{array}$ & [109] \\
\hline $\begin{array}{l}\text { Danube in the Belgrade region, } \\
\text { Serbia/early autumn, } 2012\end{array}$ & $\mathrm{Cu}, \mathrm{Fe}, \mathrm{Zn}, \mathrm{Ni}, \mathrm{Pb}, \mathrm{Cd}, \mathrm{Hg}$, As & AAS & $\begin{array}{l}\text { Surface waters ( } \mu \mathrm{g} / \mathrm{L}): \mathrm{Zn}(32) ; \mathrm{Fe}(330) ; \mathrm{Cu}(4) ; \mathrm{As}(4) \text {. } \\
\text { Sediments }(\mathrm{mg} / \mathrm{kg}): \mathrm{Zn}(139.4) ; \mathrm{Fe}(16,104) ; \mathrm{Cu}(35.95) ; \\
\text { As (8.9); } \mathrm{Cd}(0.610) ; \mathrm{Hg}(0.690) ; \mathrm{Pb}(32.58) \\
\text { Fish muscle (mg/kg DW): } \mathrm{Pb}(0.014-0.048) ; \mathrm{Cd} \\
(0.008-0.014) ; \mathrm{Hg}(0.140-0.327) ; \mathrm{As}(0.003-0.036)\end{array}$ & [110] \\
\hline $\begin{array}{l}\text { Tisa River/July, August and September of } \\
2001\end{array}$ & $\mathrm{Cd}, \mathrm{As}, \mathrm{Hg}, \mathrm{Cu}, \mathrm{Zn}, \mathrm{Cr}, \mathrm{Pb}, \mathrm{Ni}$ & FAAS with a hydride vapour system & $\begin{array}{l}\text { Sediments (mg/kg): Cu (1.96-33.1); Cr (0.440-7.640); Zn } \\
\text { (3.75-158); } \mathrm{Pb}(0.6-32.5) ; \mathrm{Cd}(0.15-1.04) ; \mathrm{Ni}(0.71-11.1) ; \\
\mathrm{As}(0.06-0.68) ; \mathrm{Hg}(0.02-0.09)\end{array}$ & [106] \\
\hline $\begin{array}{l}\text { Five sites along Yantra River, } \\
\text { Bulgaria/2013-2018 (four times per year, } \\
\text { once every three months) }\end{array}$ & $\begin{array}{l}\mathrm{Fe}, \mathrm{Mn}, \mathrm{Mg}, \mathrm{Ca}, \mathrm{Cd}, \mathrm{Hg}, \mathrm{As}, \mathrm{Cu}, \mathrm{Cr}, \mathrm{Zn}, \\
\mathrm{Pb} \text { and } \mathrm{Ni}\end{array}$ & $\begin{array}{l}\text { ICP-OES, } \\
\text { (method: ISO 011885) }\end{array}$ & $\begin{array}{l}\text { Surface Waters ( } \mu \mathrm{g} / \mathrm{L}): \mathrm{Mn}(10.35-19.97) ; \mathrm{Fe}(48.6-185.1) ; \\
\mathrm{Cu}(0.006-2.85) ; \mathrm{Zn}(9.13-40.01) ; \mathrm{Pb}(0.001-1.20) ; \mathrm{Hg} \\
(0.001-68.15) ; \mathrm{Cd}(0.002-14.90) ; \mathrm{As}(1.06-10.1) ; \mathrm{Cr} \\
(0.01-1.87 ;) \mathrm{Ni}(2.02-4.1) \\
\text { Expresed as mean value/site }\end{array}$ & [111] \\
\hline $\begin{array}{l}120 \text { sites on the Begej canal, at the border } \\
\text { between Romania and Serbia/ } \\
\text { 2008-2016 }\end{array}$ & $\mathrm{Ni}, \mathrm{Zn}, \mathrm{Cd}, \mathrm{Cr}, \mathrm{Cu}, \mathrm{Pb}$, As and $\mathrm{Hg}$ & $\begin{array}{l}\text { FAAS and GFAAS } \\
\text { (methods USEPA 3051A, 2007a, } \\
\text { 2007b) }\end{array}$ & $\begin{array}{l}\text { Sediments (sludge layer) (mg/kg): Ni (3.24-143); } \mathrm{Zn} \\
\text { (204-975); Cd (0.25-3.26); Cr (71-391); Cu (94-200); Pb } \\
\text { (8.95-263); As (8.5-43); Hg (0.04-0.97); }\end{array}$ & [84] \\
\hline
\end{tabular}


Table 5. Cont.

\begin{tabular}{|c|c|c|c|c|}
\hline Sampling Site/Sampling Moment (Data) & Monitored Contaminants & Analytical Approach & $\begin{array}{l}\text { Relevant Environmental Concentrations Range for } \\
\text { the Detected Compounds in Analysed Matrices }\end{array}$ & Ref. \\
\hline Danube river ( $\mathrm{km} 1049$ and $\mathrm{km} \mathrm{630)/2010}$ & $\begin{array}{l}32 \text { elements (Ag, As, } \mathrm{Au}, \mathrm{Ba}, \mathrm{Br}, \mathrm{Ca}, \mathrm{Ce} \\
\mathrm{Co}, \mathrm{Cr}, \mathrm{Cs}, \mathrm{Eu}, \mathrm{Fe}, \mathrm{Hf}, \mathrm{Hg}, \mathrm{K}, \mathrm{La}, \mathrm{Lu}, \mathrm{Na} \text {, } \\
\mathrm{Ni}, \mathrm{Rb}, \mathrm{Sb}, \mathrm{Sc}, \mathrm{Se}, \mathrm{Sm}, \mathrm{Sr}, \mathrm{Ta}, \mathrm{Tb}, \mathrm{Th}, \mathrm{U}, \\
\text { W, } \mathrm{Zn} \text { and } \mathrm{Zr} \text { ) }\end{array}$ & INAA & $\begin{array}{l}\text { Surface Waters ( } \mu \mathrm{g} / \mathrm{L}) \text { : As (2.35); Co (1.05); Fe (2.02); Hg } \\
(0.117) ; \mathrm{Ni}(9.9) \\
\text { Fish (mg/kg WW): As (0.029-0.204); Cr (0.06-1.63); Hg } \\
\text { (0.0031-0.027); Ni (0.084-0.412); Co (0.0058-0.121); Sb } \\
\text { (0.0021-0.0139); Zn (0.0124-0.0825); Rb (0.00093-0.004); } \\
\text { Fe (13.7-64.1); Se (0.0058-0.0507) }\end{array}$ & [112] \\
\hline $\begin{array}{l}\text { Danube river between } 347 \mathrm{~km} \text { and } 333 \\
\mathrm{~km} / 2011-2013 \text {, monthly monitoring }\end{array}$ & $\mathrm{Cd}, \mathrm{Pb}, \mathrm{Ni}, \mathrm{Cu}, \mathrm{Cr}$, and $\mathrm{Zn}$ & AAS & $\begin{array}{l}\text { Surface waters ( } \mu \mathrm{g} / \mathrm{L}) \text { : } \mathrm{Cd}(0.02-0.19) ; \mathrm{Pb}(0.05-3.81) ; \mathrm{Ni} \\
(0.33-4.92) ; \mathrm{Cu}(0.44-7.81) ; \mathrm{Cr}(0.21-3.97) ; \mathrm{Zn}(0.40-79.00) \\
\text { Sediments }(\mathrm{mg} / \mathrm{kg}): \mathrm{Cd}(0.10-0.78) ; \mathrm{Pb}(0.42-77.67) ; \mathrm{Ni} \\
\text { (11.93-93.52); } \mathrm{Cu}(7.24-86.52) ; \mathrm{Cr}(4.09-68.15) ; \mathrm{Zn} \\
\text { (32.05-302.52) }\end{array}$ & [113] \\
\hline $\begin{array}{l}10 \text { sampling sites on the Lower Danube } \mathrm{km} \\
375-175 \text { section (Romanian } \\
\text { territory)/2011-2017 }\end{array}$ & As, $\mathrm{Cd}, \mathrm{Cr}, \mathrm{Cu}, \mathrm{Pb}, \mathrm{Hg}$, Zn, Ni & AAS & $\begin{array}{l}\text { Surface sediments }(\mathrm{mg} / \mathrm{kg}) \text { : As }(06-16.96) ; \mathrm{Cd} \\
\text { (0.02-1.33); Cr (1.86-99.87); Cu (2.65-126.52); Pb } \\
(0.42-84.75) ; \mathrm{Hg}(0.02-0.52) ; \mathrm{Zn}(28.29-217.43) ; \mathrm{Ni} \\
(10.08-99.67)\end{array}$ & [85] \\
\hline $\begin{array}{l}\text { Two sites along lower sector of the Danube } \\
\text { River, at rkm } 150 \text { and } 170 \text { (Romanian } \\
\text { territory) } \\
\text { / April-May } 2018\end{array}$ & $\mathrm{Cd}, \mathrm{Pb}, \mathrm{Ni}, \mathrm{Cu}, \mathrm{Fe}, \mathrm{Zn}$ & FAAS with HR-CS-GF-AAS & $\begin{array}{l}\text { Surface waters }(\mu \mathrm{g} / \mathrm{L}): \mathrm{Cd}(0.158-0.243) ; \mathrm{Pb}(2.76-3.67) \\
\mathrm{Ni}(5.65-7.20) ; \mathrm{Cu}(5.70-9.59) ; \mathrm{Zn}(16.27-38.9) ; \mathrm{Fe} \\
(722.65-1244.68) \\
\text { (Expresed as mean values/site) }\end{array}$ & [114] \\
\hline $\begin{array}{l}\text { Five reservoirs of the Olt River September, } \\
2014\end{array}$ & $\begin{array}{l}\text { Total } \mathrm{Hg}(\mathrm{THg}) \text {, inorganic } \mathrm{Hg}(\mathrm{IHg}) \\
\text { methylmercury }(\mathrm{MeHg})\end{array}$ & AAS & $\begin{array}{l}\text { Surface waters }(\mu \mathrm{g} / \mathrm{L}) \text { : } \mathrm{THg}(0.52-2.36) \text { in water; } \\
\text { Biota }(\mathrm{mg} / \mathrm{kg} \mathrm{DW}) \mathrm{THg}(0.034-0.098) \mathrm{DW} \text { in biota; } \\
\text { Sediments }(\mathrm{mg} / \mathrm{kg}): \mathrm{THg}(0.75-1.7) ; \mathrm{MeHg}(2.5-18.6)\end{array}$ & [115] \\
\hline $\begin{array}{l}22 \text { sites along Olt river (middle and inferior } \\
\text { course)/ } \\
\text { March-May } 2018\end{array}$ & $\mathrm{Zn}, \mathrm{Cr}, \mathrm{Cu}, \mathrm{Ni}, \mathrm{Pb}, \mathrm{As}, \mathrm{Cd}, \mathrm{Hg}$ & ICP-MS & $\begin{array}{l}\text { Surface sediments }(\mathrm{mg} / \mathrm{kg}): \mathrm{Zn}(3.20-160) ; \mathrm{Cr} \\
(0.009-100.66) ; \mathrm{Cu}(0.125-52.02) ; \mathrm{Ni}(5.68-86.31) ; \mathrm{Pb} \\
(1.74-49.63) ; \mathrm{As}(10.00-242.13) ; \mathrm{Cd}(0.008-1.23) ; \mathrm{Hg} \\
(0.01-1.105)\end{array}$ & [116] \\
\hline
\end{tabular}


Table 5. Cont.

\begin{tabular}{|c|c|c|c|c|}
\hline Sampling Site/Sampling Moment (Data) & Monitored Contaminants & Analytical Approach & $\begin{array}{l}\text { Relevant Environmental Concentrations Range for } \\
\text { the Detected Compounds in Analysed Matrices }\end{array}$ & Ref. \\
\hline $\begin{array}{l}28 \text { sites along Olt river (middle and inferior } \\
\text { course)/May, July, and September } 2019\end{array}$ & $\begin{array}{l}\mathrm{Al}, \mathrm{As}, \mathrm{Cd}, \mathrm{Co}, \mathrm{Cu}, \mathrm{Cr}, \mathrm{Fe}, \mathrm{Hg}, \mathrm{Mn}, \mathrm{Ni} \\
\mathrm{Pb}, \mathrm{Zn}\end{array}$ & $\begin{array}{l}\text { ICP-MS and AAS, method ISO } \\
\text { 11047:1998 }\end{array}$ & $\begin{array}{l}\text { Surface water }(\mu \mathrm{g} / \mathrm{L}) \text { : Cr (2-64); Mn (0.8-468); Co } \\
(0.02-10) ; \mathrm{Ni}(0.05-87) ; \mathrm{Cu}(0.2-12) ; \mathrm{As}(0.02-6.9) ; \mathrm{Cd} \\
(0.01-6.5) ; \mathrm{Pb}(0.04-1.8) ; \mathrm{Hg}(0.01-1.5) ; \mathrm{Zn}(0.1-38) ; \mathrm{Fe} \\
\text { (1-1264); } \mathrm{Al}(\mathrm{ND}-2991) \\
\text { Sediments (mg/kg): Cr (ND-72); Mn (137-2273); Co } \\
\text { (ND-29); Ni (0.2-86); Cu (0.08-56); As (ND-8.3); Cd } \\
\text { (0.1-0.5); Pb (0.05-21); } \mathrm{Hg}(0.01-0.2) ; \mathrm{Zn}(7.6-524) ; \mathrm{Fe} \\
\text { (ND-14053); Al (3719-30819) }\end{array}$ & [107] \\
\hline $\begin{array}{l}\text { Two sites in low Danube region, Galati }(\mathrm{km} \\
150) \text { and Tulcea }(\mathrm{km} \text { 71)/ August } 2010\end{array}$ & $\mathrm{Cd}, \mathrm{Cu}, \mathrm{Zn}, \mathrm{Pb}$ & $\begin{array}{l}\text { AAS (air/acetyene flame); GC with } \\
\text { ECD. }\end{array}$ & $\begin{array}{l}\text { Surface waters ( } \mu \mathrm{g} / \mathrm{L}):: \mathrm{Cd}(15.7-18.4) ; \mathrm{Cu}(93.5-112.3) \text {; } \\
\mathrm{Zn}(32.58-47) ; \mathrm{Pb}(14.6-21.4) \\
\text { Fish (DW): Cd (0.010-0.091); Cu (1.5-5.34); Zn (21.92-44. } \\
\text { 5); } \mathrm{Pb}(0.26-0.65)\end{array}$ & [117] \\
\hline $\begin{array}{l}\text { Danube River, South-Western part of } \\
\text { Romania/ } \\
\text { December } 2010 \text { and July } 2012\end{array}$ & $\mathrm{Cd}, \mathrm{Cu}, \mathrm{Pb}, \mathrm{Zn}$ & ICP-MS & $\begin{array}{l}\text { Surface waters }(\mu \mathrm{g} / \mathrm{L}):: \mathrm{Cd}(0.002-0.008) ; \mathrm{Cu}(1.46-3.17) ; \\
\mathrm{Pb}(\mathrm{ND}-2.76) ; \mathrm{Zn}(0.78-1.82) \\
\text { Plants (mg/kg DW): Cd (0.65-3.52); Cu (6.24-22.71); Pb } \\
(1.51-20.06) ; \mathrm{Zn}(15.63-104.23)\end{array}$ & [118] \\
\hline $\begin{array}{l}\text { Cruhlig Lake, Danube Delta, south of the Sf. } \\
\text { Gheorghe branch/2013 }\end{array}$ & $\begin{array}{l}\mathrm{Al}, \mathrm{As}, \mathrm{Cd}, \mathrm{Co}, \mathrm{Cs}, \mathrm{Cr}, \mathrm{Cu}, \mathrm{Fe}, \mathrm{Hg}, \mathrm{K}, \mathrm{Li} \\
\mathrm{Mg}, \mathrm{Mn}, \mathrm{Ni}, \mathrm{Pb} \text { and } \mathrm{Zn}\end{array}$ & ICP-MS & $\begin{array}{l}\text { Sediments (mg/kg): } \mathrm{Al}(0.7-16.35) ; \mathrm{As}(1.7-158.24) ; \mathrm{Cd} \\
(0.0034-0.824) ; \mathrm{Co}(0.5-12.5) ; \mathrm{Cr}(0.055-38.53) ; \mathrm{Cu} \\
(0.06-46.2) ; \mathrm{Hg}(0.0278-0.520) ; \mathrm{Li}(2.4-26.77) ; \mathrm{Zn} \\
(0.1-90.8) ; \mathrm{Pb}(0.50-11.18) ; \mathrm{Fe}(1380-24650) ; \mathrm{Mn} \\
(244.8-1377)\end{array}$ & [120] \\
\hline $\begin{array}{l}\text { S-E of the Danube Delta, the Sf. Gheorghe } \\
\text { Branch/ } \\
\text { October 2012-September } 2013\end{array}$ & $\mathrm{~Pb}, \mathrm{Cd}, \mathrm{As}, \mathrm{Hg}$ & $\begin{array}{l}\text { electrothermal (ETAAS) method and } \\
\text { HGAAS }\end{array}$ & $\begin{array}{l}\text { Sediments (mg/kg): Pb (5.44-47.45); As (1.13-20.55); Cd } \\
(0.04-1.34) ; \mathrm{Hg}(0.005-0.99)\end{array}$ & [121] \\
\hline $\begin{array}{l}\text { Danube Delta Biosphere Reserve (four } \\
\text { aquatic complexes)/ } \\
\text { 2007-2011 }\end{array}$ & $\mathrm{Mg}, \mathrm{Cu}, \mathrm{Rh}, \mathrm{Cd}, \mathrm{In}, \mathrm{Ba}, \mathrm{Ce}, \mathrm{Pb}$ & ICP-MS & $\begin{array}{l}\text { Surface waters ( } \mu \mathrm{g} / \mathrm{L}): \mathrm{Mn}(54.67-251.74) ; \mathrm{Pb} \\
\text { (6.81-48.04); Ni (27.15-104.28); } \mathrm{Cr}(26.00-81.24) ; \mathrm{Zn} \\
\text { (124.5-333.78); Cd (4.21-11.05) } \\
\text { Plankton (mg/kg DW): Cd (2874-42.356); Cr } \\
\text { (3.658-24.362); Mn (1.104-29.714); Ni (7.440-27.890); } \\
\mathrm{Pb}(0.118-1.014) ; \mathrm{Zn}(10.959-74.644)\end{array}$ & [122] \\
\hline
\end{tabular}


Table 5. Cont.

\begin{tabular}{|c|c|c|c|c|}
\hline Sampling Site/Sampling Moment (Data) & Monitored Contaminants & Analytical Approach & $\begin{array}{l}\text { Relevant Environmental Concentrations Range for } \\
\text { the Detected Compounds in Analysed Matrices }\end{array}$ & Ref. \\
\hline $\begin{array}{l}\text { Biosphere Reservation of Danube } \\
\text { Delta/three time per year during 2007-2015 }\end{array}$ & $\mathrm{Cd}, \mathrm{Cr}, \mathrm{Mn}, \mathrm{Ni}, \mathrm{Pb}$ and $\mathrm{Zn}$ & ICP-MS & $\begin{array}{l}\text { Surface waters ( } \mu \mathrm{g} / \mathrm{L}) \text { : Cd (3.5-10.5); } \mathrm{Cr}(22.6-76.2) ; \mathrm{Mn} \\
\text { (72.8-178.2); Ni (27.8-76.4); } \mathrm{Pb}(6.11-11.2) ; \mathrm{Zn} \\
(100.2-209.8) \\
\text { Sediment }(\mathrm{mg} / \mathrm{kg}): \mathrm{Cd}(3.47-7.88) ; \mathrm{Cr}(29.4-117.6) ; \mathrm{Mn} \\
\text { (301.9-687.9); Ni (27.1-79.1); } \mathrm{Pb}(5.18-13.99) ; \mathrm{Zn} \\
\text { (122.1-204.7) } \\
\text { Aquatic plants (mg/kg DW): Cd (0.447-2.026); Cr } \\
\text { (0.967-5.107); } \mathrm{Mn}(0.286-3.889) ; \mathrm{Ni}(1.630-14.052) ; \mathrm{Pb} \\
\text { (0.160-5.792); Zn (5.741-25.284) }\end{array}$ & [123] \\
\hline $\begin{array}{l}4 \text { sampling sites in Danube Delta Biosphere } \\
\text { Reserve (Matita-Merhei)/ } \\
\text { 2006-2015, seasonal monitoring in spring, } \\
\text { summer and autumn }\end{array}$ & $\mathrm{Ni}, \mathrm{Cr}, \mathrm{Pb}, \mathrm{As}$ & ICP-MS & $\begin{array}{l}\text { Surface waters }(\mu \mathrm{g} / \mathrm{L}) \text { : As (7.96-16.25); Ni (19.10-79.10); } \\
\mathrm{Cr}(12.5-78.25) ; \mathrm{Pb}(5.5-34) \\
\text { Sediments (mg/kg): As (1.9-9.42); Ni (5.14-21.35); Cr } \\
\text { (9.20-17.68); Pb (1.9-9.42) }\end{array}$ & [124] \\
\hline $\begin{array}{l}\text { The reservoir Stanca-Costesti, on the } \\
\text { middle course of the Prut River/ } \\
\text { July, } 2015 \text { and April } 2015\end{array}$ & $\mathrm{Cu}, \mathrm{Cd}, \mathrm{Pb}, \mathrm{Cr}$ and $\mathrm{Ni}$ & HR-CS-GF-AAS & $\begin{array}{l}\text { Sediments (mg/kg): Cu (1.86-5.01); Cd (0.026-0.202); Pb } \\
\text { (1.33-3.36); } \mathrm{Cr}(2.16-6.26) ; \mathrm{Ni}(3.1-8.05) \\
\text { Mollusch (mg/kg DW): Cu (0.93-41.67); Cd } \\
(0.049-0.099) ; \mathrm{Pb}(0.07-0.53) ; \mathrm{Cr}(0.22-1.52) ; \mathrm{Ni} \\
(0.47-1.81)\end{array}$ & [125] \\
\hline $\begin{array}{l}\text { Seven sites along the Danube River, } \\
\text { Danube Delta and Black Sea/ } \\
\text { April } 2018\end{array}$ & $\begin{array}{l}\mathrm{Ca}, \mathrm{Mg}, \mathrm{Na}, \mathrm{K}, \mathrm{Fe}, \mathrm{Zn}, \mathrm{Cu}, \mathrm{Ni}, \mathrm{As}, \mathrm{Cd} \\
\mathrm{Pb}, \mathrm{Cr}\end{array}$ & $\begin{array}{l}\text { FAAS; } \\
\text { HR-CS-GF-AAS }\end{array}$ & $\begin{array}{l}\text { Surface waters }(\mu \mathrm{g} / \mathrm{L}) \text { : } \mathrm{Zn}(0.5-57) ; \mathrm{Fe}(100-1500) ; \mathrm{Ni} \\
(1-11) ; \mathrm{Pb}(0.5-3.1) ; \mathrm{As}(1.7-3.9) ; \mathrm{Cu}(0.5-6.7) ; \mathrm{Cd} \\
(0.004-0.14) \\
\text { Sediment }(\mathrm{mg} / \mathrm{kg}): \mathrm{Zn}(17-150) ; \mathrm{Fe}(3000-22000) ; \mathrm{Cu} \\
(2-40) ; \mathrm{Cr}(5-26) ; \mathrm{Ni}(5.2-39.8) ; \mathrm{As}(1.4-13) ; \mathrm{Pb}(2-12) ; \mathrm{Cd} \\
(0.01-0.7) \\
\text { Fish muscle (mg/kg WW): } \mathrm{Pb}(0.002-0.024) ; \mathrm{Cd} \\
(0.001-0.15) ; \mathrm{As}(0.3-0.5) ; \mathrm{Cu}(0.2-5.4) ; \mathrm{Fe}(4-72) ; \mathrm{Zn} \\
(3.6-37.9)\end{array}$ & [126] \\
\hline The Romanian Black Sea coastline June 2014 & $\mathrm{Hg}, \mathrm{Cd}, \mathrm{Pb}, \mathrm{Ni}, \mathrm{Cr}, \mathrm{Mn}, \mathrm{Zn}$, and $\mathrm{Cu}$ & ICP-MS & $\begin{array}{l}\text { Microalgae species (mg/kg DW): Mn (22.94-612.34); Zn } \\
\text { (33.03-119.02); Cu (0.28-13.85); Ni 0(.41-6.30); Hg } \\
(0.00214-0.00876) ; \mathrm{Cr}(0.003-1.77) ; \mathrm{Pb}(0.10-1.83) ; \mathrm{Cd} \\
(0.05)\end{array}$ & [127] \\
\hline
\end{tabular}


Table 5. Cont.

\section{Sampling Site/Sampling Moment (Data) Monitored Contaminants}

Black Sea coastline April 2011 and October 2012
$\mathrm{Cd}, \mathrm{Pb}, \mathrm{Cr}, \mathrm{Ni}$, and $\mathrm{Cu}$

AAS with graphite furnace

\section{Analytical Approach}

Relevant Environmental Concentrations Range for the Detected Compounds in Analysed Matrices

Surface waters ( $\mu \mathrm{g} / \mathrm{L})$ : Cu (3.06-30.66); Cd (0.41-2.72);

$\mathrm{Pb}(4.03-12.93)$; Ni (2.50-2.70); Cr (0.67-2.19)

Sediments (mg/kg): Cu (17.76-26.68); Cd (0.90-1.20); Pb

(8.40-11.59); Ni (22.15-26.25); Cr (24.5-30.26)

Algae (mg/kg DW): Cu (0.33-17.44); Cd (0.29-0.33); Pb

(5.26-6.48); Ni (12.3-13.08); Cr (4.78-6.70)

Molluscs (mg/kg DW): Cu (2.71-18.32); Cd (0.20-1.64);

$\mathrm{Pb}$ (0.07-1.36); Ni (0.52-1.05); Cr (0.16-0.89)

Fish (mg/kg DW)Cu (1.91-3.48); Cd (0.02-0.06); Pb

(0.07-0.32); Ni (0.06-0.25); Cr (0.02-0.11)

Bulgarian Black Sea coast/

As, $\mathrm{Hg}, \mathrm{Cd}, \mathrm{Mn}, \mathrm{Pb}$

AAS and ETAAS

Molluscs (mg/kg DW) Mn (0.26-1.74); As (2.07-4.17); Cd

(0.005-0.090); Pb (0.11-0.32); Hg (0.08-0.32), (DW)

Surface waters ( $\mu \mathrm{g} / \mathrm{L})$ : $\mathrm{Cu}(2.5-6.2)$; Zn (20-47)

Fish (mg/kg WW): Cu (19.9-42.2 in liver); (3.6-28.5 in

muscle);

Zn (29.9-56 in liver); (8.7-30.2 in muscle);

Surface waters ( $\mu \mathrm{g} / \mathrm{L})$ : As (1.34-6.92); Hg (0.009-0.080);

Zn (5.77-108); Cu (1.26-10.8); Cr (0.26-4.38)

Sediment (mg/kg): As (2.36-8.93); $\mathrm{Hg}(0.012-0.501) ; \mathrm{Zn}$

(42.6-167); Cu (0.61-26.6); Cr (30.7-108); Cd

(0.208-0.757); Pb (11.7-31.7); Ni (13.3-49.5)

Ref.

Dniester River Basin (Ukraine and Republic of Moldova)/

As, $\mathrm{Hg}, \mathrm{Zn}, \mathrm{Cu}, \mathrm{Cr}, \mathrm{Cd}, \mathrm{Pb}, \mathrm{Ni}$

ICP-MS

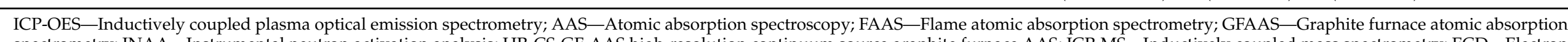

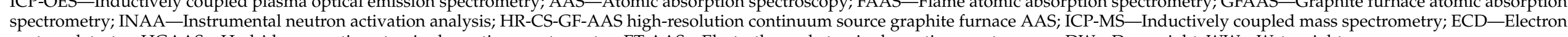
capture detector; HGAAS—Hydride generation atomic absorption spectrometry; ET-AAS—Electrothermal atomic absorption spectroscopy; DW—Dry weight; WW—Wet weight. 
Surface waters were analyzed in 17 studies, sediments in 16, and biota (fish species, mollusks, plankton, aquatic plants, and microalgae) in 15 studies. A number of six complex studies considered water, sediments, and biota. As environmental pollution with heavy metals is well regulated, sampling, sample preparation, and analysis are generally carried out according to specific standards, e.g., ISO 5667-3:2018 [131] for water sampling, sample preservation, transport, and storage, ISO 5667-13:2011 [132] for sediments sampling, ISO 15587-1/2:2002 [133,134] for water sample preparation, ISO 17294-2:2016 [135] concerning the ICP-MS method, ISO 11047:1998 [136] concerning flame and electrothermal AA for analysis.

The most frequently reported metals, in the following decreasing order, were: $\mathrm{Pb}, \mathrm{Cd}$, $\mathrm{Ni}, \mathrm{Cr}, \mathrm{As}, \mathrm{Cu}, \mathrm{Zn}, \mathrm{Hg}, \mathrm{Mn}, \mathrm{Fe}, \mathrm{Co}, \mathrm{Al}$. The reported values show large variation for all matrices (Figure 7).
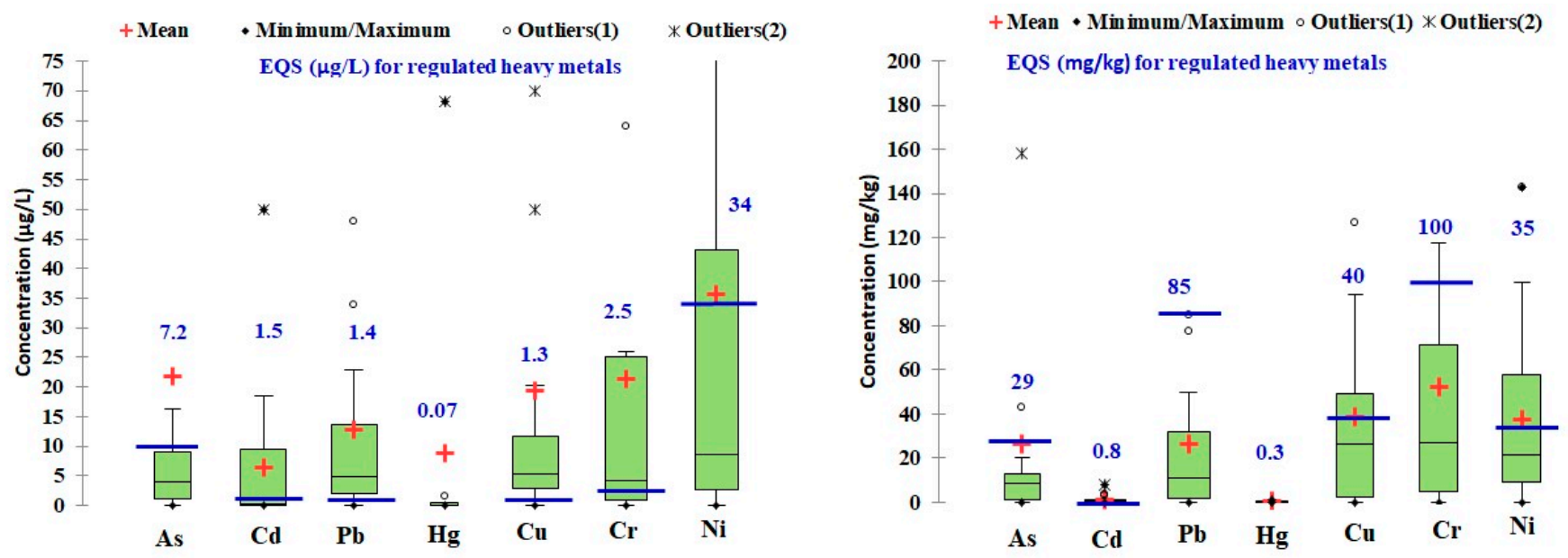

Figure 7. Concentration range of the seven most-reported metals in surface water (left) and sediments (right) compared to the maximum acceptable concentration (MAC-EQS) according to the Decisions 2013/39/EU and Order 161/2006 (Romanian regulation).

Regarding spatial distribution of metal concentrations in water, it can be observed that, in general, the highest concentrations were reported for tributaries, followed by those in the Danube Delta biosphere Reserve, the lowest concentrations being reported in the Danube River.

Thus, for $\mathrm{Cd}$, a concentration range of $0.002-1.33 \mu \mathrm{g} / \mathrm{L}$ was reported in the Danube River, values of $50 \mu \mathrm{g} / \mathrm{L}$ were measured in the tributary Morava River, Serbia [109], and of $14.90 \mu \mathrm{g} / \mathrm{L}$ in the tributary Yantra River, Bulgaria [111] as a maximum of $11.05 \mu \mathrm{g} / \mathrm{L}$ in the Biosphere Reservation of the Danube Delta [123]. Similarly, Cu reported concentrations varying within a range $2.65-10.1 \mu \mathrm{g} / \mathrm{L}$, except the maximum value of $112.3 \mu \mathrm{g} / \mathrm{L}$ in the Danube, reported in the Danube in sampling sites corresponding to a large industrial city (Galaţi town) [117]. In the tributary Tisa River, a concentration of $70 \mu \mathrm{g} / \mathrm{L}$ was measured [109], as a value of $6.7 \mu \mathrm{g} / \mathrm{L}$ was reported in the Danube Delta [126]. Although lower concentrations of metals in seawater have generally been reported for $\mathrm{Cu}$, a maximum value of $30.66 \mu \mathrm{g} / \mathrm{L}$ was measured by Jitar et al. [128].

$\mathrm{Cr}$ concentrations ranged from $0.21 \mu \mathrm{g} / \mathrm{L}$ to $9 \mu / \mathrm{L}$ in the Danube River. A maximum concentration of $64 \mu \mathrm{g} / \mathrm{L}$ was reported in Olt River [107], as comparable maximum concentrations of $81.24 \mu \mathrm{g} / \mathrm{L}$ [122] and $78.25 \mu \mathrm{g} / \mathrm{L}$ [124] were measured in the Biosphere Reservation of the Danube Delta. A similar trend was observed for $\mathrm{Hg}$, with concentration range of $0.001-0.117 \mu \mathrm{g} / \mathrm{L}$ in the Danube and a maximum value of $68.15 \mu \mathrm{g} / \mathrm{L}$ reported in the Yantra River, Bulgaria [117]. Low concentrations of $\mathrm{Pb}$ are generally reported in the Danube river in a range of $0.003-3.81 \mu \mathrm{g} / \mathrm{L}$ with the exception of a maximum value of $21.4 \mu \mathrm{g} / \mathrm{L}$ reported near the Galaţi town by Ionita et al. [117]. However, considerably 
higher concentrations of $48.04 \mu \mathrm{g} / \mathrm{L}$ [122] and $34 \mu \mathrm{g} / \mathrm{L}$ [124] of Pb were reported in the Danube Delta Biosphere reserve. For As, concentration range of $0.5-16.96 \mu \mathrm{g} / \mathrm{L}$ was reported in the Danube River, a maximum of $10.1 \mu \mathrm{g} / \mathrm{L}$ in the tributary Yantra River [111], and a maximum of $16.25 \mu \mathrm{g} / \mathrm{L}$ in the Danube Delta [124].

Regarding the concentrations of metals in sediments, in general, the lowest concentration values were reported for the Danube Delta followed by those in the Danube River. Significantly higher values were reported for tributary, especially where sampling was carried out from reservoirs or between of shipping locks.

Thus, a concentration range of $1.96-126.52 \mathrm{mg} / \mathrm{kg} \mathrm{Cu}$ in sediments was measured in the Danube River [85] and $40 \mathrm{mg} / \mathrm{kg}$ in the Danube Delta [126], whereas, a maximum concentration of $263 \mathrm{mg} / \mathrm{kg}$ was reported in the Begej canal [84]. A similar trend was observed for $\mathrm{Pb}, \mathrm{Hg}, \mathrm{Cd}, \mathrm{As}, \mathrm{Zn}$, and $\mathrm{Cr}$. For example, concentration ranges of $0.42-84.75 \mathrm{mg} / \mathrm{kg}$ for $\mathrm{Pb}$ [85] and of $0.02-0.690 \mathrm{mg} / \mathrm{kg}$ for $\mathrm{Hg}$ [110] were reported in the Danube river, and maximum values of $47.45 \mathrm{mg} / \mathrm{kg}$ for $\mathrm{Pb}$ and $0.99 \mathrm{mg} / \mathrm{kg}$ for $\mathrm{Hg}$ were reported by Gati et al. in the Sf. Gheorghe Branch of the Danube Delta [121], while a maximum value of $263 \mathrm{mg} / \mathrm{kg}$ $\mathrm{Pb}$ was measured in the Begej canal [84] and $1.7 \mathrm{mg} / \mathrm{kg} \mathrm{Hg}$ in the Olt river reservoirs [115]. Comparable maximum values were reported in the Danube River and Danube Delta for Cd (1.33 mg/kg [85] and $1.34 \mathrm{mg} / \mathrm{kg}$ respectively [121], and $\mathrm{Zn} \mathrm{(217} \mathrm{mg} / \mathrm{kg}$ [85] and $209.8 \mathrm{mg} / \mathrm{kg}$ [123]), whereas, maximum values of $3.26 \mathrm{mg} / \mathrm{kg} \mathrm{Cd}$ and $975 \mathrm{mg} / \mathrm{kg} \mathrm{Zn}$ were measured in the Begej Canal [84]. For As, a concentration range of 1.06-16.96 was reported in the Danube river, a maximum concentration of $20.55 \mathrm{mg} / \mathrm{kg}$ was measured in the Sf. Gheorghe Branch of the Danube Delta [121], and $43 \mathrm{mg} / \mathrm{kg}$ in the Begej canal [84].

Four multi-annual studies were identified concerning the presence of metals in water, sediment, and fish $[85,111,123,130]$. A descendant trend in the concentrations of $\mathrm{Pb}$ and $\mathrm{Zn}$ in water samples from the Somova-Parcheş aquatic complex (Danube delta) between 2007-2012 was reported by Burada et al. [123] and attributed to "reducing emissions from the surrounding industrial activity". In the lower section of the Danube River (km 375-km 175), mostly homogeneous evolution in time of metals concentrations in sediments was reported by Radu et al. in a six-year study [85]. There were seasonal and age-dependent dynamics of $\mathrm{Cu}$ and $\mathrm{Zn}$ in different freshwater fish in Dniester and Prut for the period between 2005 and 2010 [130].

The concentrations of heavy metals in sediments revealed seasonal variation and significant differences between the sampling sites [107,113,123]. The bioaccumulation capacity of these pollutants was studied by determining metals in microalgae [127] aquatic plants [128], plankton [122], mollusks [129], and fish [117,137]. However, the diversity of the species studied, differences in the expression of the results (dry weight or wet weight), or different target analytes led to a difficult comparative analysis of the results. Nevertheless, the studies showed correlations between the heavy metals concentrations in water, sediments and the biota, especially for $\mathrm{As}, \mathrm{Cd}, \mathrm{Pb}, \mathrm{Cu}, \mathrm{Ni}, \mathrm{Cr}, \mathrm{Hg}$, $\mathrm{Co}$, and $\mathrm{Zn}$, with various bio-concentration factors (BCF) depending on the biota species [109,123,125,128,129].

Exceeding of the maximum allowable concentration of heavy metals in surface waters according to the Directive 2013/39/EU [35] and Romanian legislation (Order 161/2006) [138] concerning environmental quality standards (EQS) for priority substances in the field of water policy were frequently reported. $\mathrm{Cd}$ concentrations exceeded the maximum EQS of $1.5 \mu \mathrm{g} / \mathrm{L}$ in the tributaries West Morava (reported value of $50 \mu \mathrm{g} / \mathrm{L}$ ) [109] and Yantra (reported value $14.9 \mu \mathrm{g} / \mathrm{L})$ [111], in the Danube river near Galati $(\mathrm{km} \mathrm{150)}$ and Tulcea ( $\mathrm{km} \mathrm{71)} \mathrm{town} \mathrm{(reported} \mathrm{values} \mathrm{of} 15.750 \mu \mathrm{g} / \mathrm{L}$ and $18.450 \mu \mathrm{g} / \mathrm{L}$ respectively) [117], and in the Biosphere Reservation of Danube Delta (reported range of 3.5-10.5 $\mu \mathrm{g} / \mathrm{L}$ ) [123]. $\mathrm{Pb}$ concentrations exceeded the EQS of $14 \mu \mathrm{g} / \mathrm{L}$ in the Danube river near Galati and Tulcea towns (reported value of $21.6 \mu \mathrm{g} / \mathrm{L}$ and $14.6 \mu \mathrm{g} / \mathrm{L}$ respectively) [117] and in the Danube Delta Biosphere Reserve (maximum value of $48.06 \mu \mathrm{g} / \mathrm{L}$ ) [122]. For Hg, concentrations exceeding the EQS of $0.07 \mu \mathrm{g} / \mathrm{L}$ were reported in the tributary Yantra River (reported value $68.15 \mu \mathrm{g} / \mathrm{L}$ ) [111], in the tributary Olt river (maximum $1.5 \mu \mathrm{g} / \mathrm{L}$ ) [107], and in the Danube river (reported value of $0.117 \mu \mathrm{g} / \mathrm{L}$ ) [112]. 
Concentrations of Ni exceeding the EQS of $34 \mu \mathrm{g} / \mathrm{L}$ were reported in the Danube Delta by Burada et al., (maximum concentration of $76.4 \mu \mathrm{g} / \mathrm{L}$ ) [123] and Despina et al., (maximum concentration of $79.1 \mu \mathrm{g} / \mathrm{L}$ ) [124]. Concentrations of $\mathrm{Cu}, \mathrm{Cr}, \mathrm{Co}$, and As exceeding the maximum allowable value of EQS according to national regulations (Order 161/2006) were reported in the Danube River [113,117,118,128], in the tributary Olt [107] and Prut rivers [130], and in the Danube Delta [122,123].

However, the values of heavy metal concentrations reported for water and sediment in the Lower Danube basin were significantly lower than those reported elsewhere. Mean concentration of $623.32 \mathrm{mg} / \mathrm{kg}$ for As, $2005.94 \mathrm{mg} / \mathrm{kg}$ for $\mathrm{Pb}, 151.09 \mathrm{mg} / \mathrm{kg}$ for Cd, $375 \mathrm{mg} / \mathrm{kg}$ for $\mathrm{Cr}$, and 4.65 for $\mathrm{Hg}$ in sediments were recently reported in Watershed of Southwestern Ethiopia [139], which is much higher than any concentration value reported for the Lower Danube basin. Comparable values for $\mathrm{Pb}, \mathrm{As}$, and $\mathrm{Cd}$ but lower for $\mathrm{Hg}$ than in the Lower Danube basin were reported in rivers from Southern Italy [140]. In the sediments from Jarama River (central Spain) average concentrations of $55.59 \mathrm{mg} / \mathrm{kg}$ for Cu, 135.6 for $\mathrm{Zn}$, $15.83 \mathrm{mg} / \mathrm{kg}$ for $\mathrm{Ni}, 1.15 \mathrm{mg} / \mathrm{kg}$ for $\mathrm{Cd}$, and $35.77 \mathrm{mg} / \mathrm{kg}$ for Pb were reported [141]. Higher values for $\mathrm{Cu}$ were reported in the Lower Danube basin by Radu et al. [85]. The measured concentration in the Danube basin for $\mathrm{Zn}, \mathrm{Ni}, \mathrm{Cd}$ and $\mathrm{Pb}$ exceeded the values reported for Jarama River in several studies [84,85,113,119,120,123].

The few studies conducted for water and sediments in the North West Black Sea do not allow extensive comparative analysis. A recent report on the heavy metal pollution over the last 20 years in the Baltic Sea [142] revealed concentration ranges of $28-90 \mathrm{mg} / \mathrm{kg}$ for Pb, 0.5-1.3 mg/kg for Cd, 1-4 mg/ kg for Ni, 20-380 mg/ kg for Cu, and 1.2-5.5 mg/kg for Co, in sediments in open sea, which are higher than those reported in the publications included in this review. In a comprehensive study on the heavy metal pollution of sediments from a coastal area of the central western Adriatic Sea [143], average concentrations of $63 \mathrm{mg} / \mathrm{kg}$ was reported for Ni, $14.4 \mathrm{mg} / \mathrm{kg}$ for Cu, $61.5 \mathrm{mg} / \mathrm{kg}$ for $\mathrm{Cr}$, and $12 \mathrm{mg} / \mathrm{kg}$ for Pb, which higher than the values reported for the Black Sea is as well. In a recent study [144], the assessment of sediments quality concerning the heavy metals $\mathrm{Cd}, \mathrm{Cr}, \mathrm{Cu}, \mathrm{Pb}, \mathrm{Zn}$ and Mn was carried out in 2019 and 2020 for the Romanian part of MONITOX Network (32 sampling points in the system of Danube river-Danube Delta-Black Sea: Lower Danube RO-BG, Lower Danube RO, Lower Prut RO-MD border, Danube Delta RO-UA border, Danube Delta-RO and Black-Sea area-RO) using both single indices and integrated indices. The research revealed that sediments from the Black Sea area were much less contaminated with heavy metals than those from the Lower Danube (Romania), attributed to the historical pollution resulting from anthropogenic activities [144].

\section{Microbiological Pollution}

The microbiological contamination of the surface water is one of the most significant health-related problems in the Danube region [145]. The available data show that both the upstream and downstream reaches on the Danube are microbiological contaminated [146]. The main sources of contamination are uncontrolled raw sewage, discharge of untreated or inadequately treated wastewaters, and impact by diffuse sources of agricultural land and pastures [146].

Bacteria are ideal sensors for indicating microbial pollution of surface water bodies due to their rapid response to changing environmental conditions. Faecal coliforms, particulary Escherichia coli as the predominant species, and intestinal enterococci are parameters for assessing faecal pollution (standard faecal indicator bacteria (SFIB)), also showing the potential presence of pathogenic bacteria, viruses, and parasites [146]. Monitoring of the standard microbiological parameters is mandatory by legislation in the field of waters bodies intended for drinking water, irrigation, and bathing according to the Water Directive [74], Urban Wastewater Treatment Directive (European Council, 1991) [147], the Bathing Water Directive (European Parliament and Council, 2006) [148], and the Drinking Water Directive (European Council, 2020) [149]. However, no regulatory values concerning microbial faecal pollution for river water in Europe are currently set. 
In order to assess the water quality in the Danube River basin, riparian countries use different methods for microbiological analysis. The method ISO 9308-2:2012 commonly used for the enumeration of E. coli and coliform bacteria in water is based on the growth of target organisms in a liquid medium and calculation of the "Most Probable Number" (MPN) of organisms by reference to MPN tables [150].

Studies published in 2014 [151] and 2017 [145] by Kirschner et al. on the microbial faecal pollution along the Danube River based on the results obtained within The Joint Danube Surveys (JDS) 2001, 2007, and 2013 reveal human faecal pollution as the primary pollution source along the whole river. The lowest Danube section showed low to moderate E. coli pollution levels $[145,151]$. However, sites downstream from Russenski Lom (rkm 488, Bulgaria, 46,900 MPN/100 mL) and Arges (rkm 429, Romania, $3100 \mathrm{MPN} / 100 \mathrm{~mL}$ ) were demonstrated as the most polluted tributaries of the whole river basin. The tributaries Iskar and Jantra (Bulgaria) showed low E. coli pollution, while in Romania, Siret and Prut were critically polluted. Concerning the Low Danube, the section between Novi Sad and Velika Morava (110-2300 MPN/100 mL) showed moderate pollution values, while downstream from Zimnicea/Svistov ( $\mathrm{rkm}$ 550) exhibited high faecal pollution (27,700 MPN/100 mL) [145].

As only the determination of the SFIB does not provide information regarding the pollution source, microbial source tracking approaches have become appropriate tools for determining the origin of microbial faecal pollution in different water ecosystems [145]. The most common methods are based on the quantitative polymerase chain reaction (qPCR) detection of host-associated Bacteroidetes populations. The human-associated faecal marker (BacHum) expressed as marker equivalents (ME) was detected in $92.4 \%$ of all the investigated Danube samples and in $100 \%$ of all the tributary samples. Furthermore, statistical analysis revealed a significant correlations between both E. coli and enterococci and human BacH marker [145]. The BacHum concentrations in the whole Danube River ranged from 250 to $1.3 \times 10^{6} \mathrm{ME} / 100 \mathrm{~mL}$, with the highest concentration measured downstream from Arges (Romania). Tributary Rusenski Lom (Bulgaria), followed by Arges (Romania) showed the highest BacHum concentrations $\left(4.5 \times 10^{6} \mathrm{ME} / 100 \mathrm{~mL}\right.$, corresponding to Arges river) [145]. In contrast to BacHum marker, the animal associated markers (BacR for ruminant, and Pig2Bac for pig) were of minor importance along the whole Danube River and major tributaries, except the Danube Delta, where the highest Pig2Bac concentration $\left(6.9 \times 10^{3} \mathrm{ME} / 100 \mathrm{~mL}\right)$ was measured in the Sulina arm and Jantra tributary with the highest BacR concentration $\left(2.9 \times 10^{3} \mathrm{ME} / 100 \mathrm{~mL}\right)$ [145].

Apart from study related to JDSs, very few studies concerning microbiological pollution on the Lower Danube basin were identified.

An industrial area of the Danube, near Galati town (rkm 155-158), was investigated from a microbiological point of view for a period of four months, from June to September 2010 [152]. The lowest value for total coliforms of $4.5 \times 10^{2} \mathrm{MPN} / \mathrm{mL}$ was measured in July, while the highest value of $2 \times 10^{4} \mathrm{MPN} / \mathrm{mL}$ in August. For faecal coliforms, the lowest pollution $\left(4.5 \times 10^{2}\right.$ colony-forming unit $\left.(\mathrm{CFU}) / \mathrm{mL}\right)$ was recorded in July, while the highest value $\left(20 \times 10^{3} \mathrm{CFU} / \mathrm{mL}\right)$ in August. Maximum E. coli pollution was recorded in September $\left(6.4 \times 10^{3} \mathrm{CFU} / \mathrm{mL}\right)$ [152].

A total of 32 different sites of MONITOX network were selected in the Lower Danube region and Romanian Black Sea coast for a recent study conducted in June 2019 and June-July 2020, concerning microbiological pollution in the Black Sea Basin [153]. Heterotrophic bacteria and total coliforms were used as microbiological indicators. The coliform bacteria were identified in all water samples ranging from $130 \mathrm{CFU} / 100 \mathrm{~mL}$ (Ostrov) and 250,000 CFU/100 mL (Calarasi/Silistra) in the Lower Danube sector and from $10 \mathrm{CFU} / 100 \mathrm{~mL}$ (Izmail) to 70,000 CFU/100 mL (Sfantu Gheorghe arm in the Danube Delta). The heterotrophic bacteria ranged from $155 \mathrm{CFU} / \mathrm{mL}$ (downstream Braila town) to $6080 \mathrm{CFU} / \mathrm{mL}$ (upstream Siret river) in the Lower Danube sector and from $111 \mathrm{CFU} / \mathrm{mL}$ (Black Sea, Mangalia town) to 17,000 CFU/mL (Sfantu Gheorghe arm) in the Danube DeltaBlack Sea area [153]. The study enabled a comparison of microbiological contamination 
of surface water in the periods before (2019) and after the (2020) COVID-19 lockdown, demonstrating a decrease of bacteria load in 2020 in all the samples collected from Black Sea coast, Danube branches, Danube-Black Sea confluence, and Danube River downwards of Galati town. For these water samples, an ongoing work is carried out in the frame of the EU-funding project BSB27-MONITOX for several CECs at "Dunarea de Jos" University of Galati, Romania using a high-resolution mass spectrometry technique.

Only a few studies on fecal pollution in the North West coast of the Black Sea were conducted in the last 10 years. Comparison between faecal and organic pollution of water samples from the Black Sea area, Romania and water samples from the Aegean Sea, Kavala, Greece were presented by Vasile et al. in 2020 [154]. Higher values of fecal indicators were measured in Black Sea compared with the Aegean Sea coast. Thus, total mesophilic aerobic bacteria in Black Sea area (Romania), ranged from $1.11 \times 10^{2}$ to $1.70 \times 10^{4} \mathrm{CFU} / \mathrm{mL}$ and of coliforms between $250 \mathrm{MPN} / \mathrm{mL}$ to $7000 \mathrm{MPN} / \mathrm{mL}$. In Aegean Sea water, no coliforms were found and the number of heterotrophic bacteria was $1.50 \times 10 \mathrm{CFU} / \mathrm{mL}$ [154].

Among the study on the eastern part of the Black Sea, a recent one investigating bacterial pollution along coastal areas in Turkey, between May 2017 and February 2018, revealed a high degree of contamination in the study area [155]. Total coliform levels ranged from $1.0 \times 10^{3} \mathrm{CFU} / 100 \mathrm{~mL}$ to $3.14 \times 10^{8} \mathrm{CFU} / 100 \mathrm{~mL}$. The fecal coliform levels ranged from $2.0 \times 10^{2} \mathrm{CFU} / 100 \mathrm{~mL}$ to $9.04 \times 10^{7} \mathrm{CFU} / 100 \mathrm{~mL}$. Bacteriological pollution increased in all sites in summer months [155]. A comparison of the results for the seawater in Romania and Turkey is difficult due to different methods and different expressions of the results.

\section{General Overview}

Continuous monitoring over the last two decades, either through point surveys or complex surveillance programs covering several years, has led to changes and continuous updates of the legislation (e.g., Commission Decisions EU 2018/840 [26] and 2020/1161 [45]), to the development of large substances databases (e.g., NORMAN [60]), and to new approaches in pollutant prioritization and risk assessment methodology [33]. The literature on monitoring programs of organic and inorganic pollutants published during 2010-2021 for the Lower Danube basin and North West Black Sea region show that this research area has been extended in the last year (Figure 8 due to the higher concern of political entities and, on the other hand, the development of more sensitive analytical techniques.

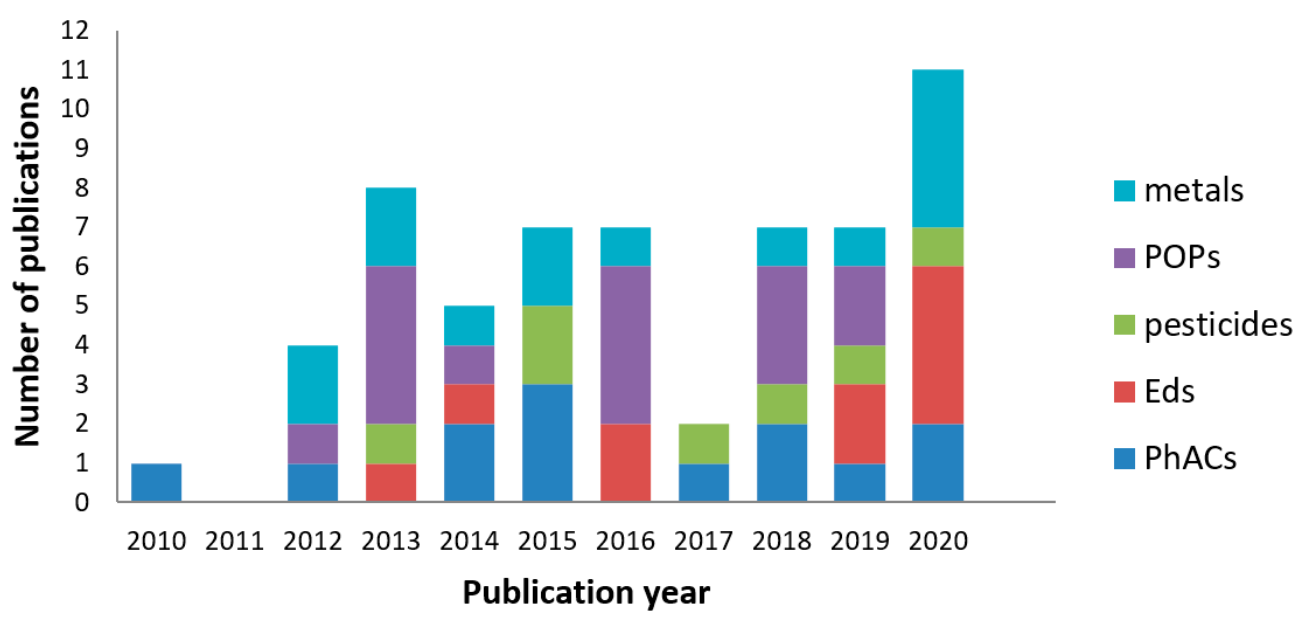

Figure 8. Frequency of reports by year (2010-2020), dealing with monitoring of the emerging contaminants, and persistent pollutants.

Some observations on the cited studies include:

- $\quad$ Most of the papers focused on the active substances and only a few on the metabolites or biodegradation products $[15,26,39,49,53]$; 
- Studies are repetitive, which is helpful in terms of pollutants dynamics but, on the other hand, not only the most frequently studied substances should be considered but also those with high risk and relevance for the environment;

- Most of the authors reported occurrence of CECs without justifying the selection of compounds. Criteria as "substances that commonly have been detected" or "ubiquitous presence" were appealed. Priority substances listed by the EU regulations or NORMAN databases were mentioned in four papers [26,44,51,77];

- Insufficient attention was paid to the natural variability of the aquatic environment, leading to inadequate data collection (e.g., substances that are susceptible to degradation caused by sunlight exposer or absorption of the pollutant on suspended particulate matter were rarely discussed). One paper concerning CECs analysis in suspended particulate matter was identified [45];

- The majority of the reviewed studies concerning CECs monitoring were based on 'grab-sampling' often with no intra-day repetition. The limitations of such an approach results in snap shots data on pollutant concentration for a specific point in time. Composite sampling that considered flow fluctuations was performed in 1 of 24 studies [15]; furthermore, chemical stability of the target analytes during storage until analysis was investigated in only one study [45];

- $\quad$ Few antibiotics are usually monitored in the studies cited in Table 1 (pharmaceuticals) despite the risk posed to aquatic and terrestrial organisms and possible occurrence of bacteria resistance;

- The analytical approach of targeted screening with low resolution mass spectrometry (e.g., triple quadrupoles) used in the majority of reviewed studies resulted in numerous substances such as metabolites or transformation products going undetected. Among 24 studies concerning CECs monitoring, tentative identification using HRMS-MS was carried out in one publication [26]. Multiresidue methods allowing targeted (quantitative) and non-targeted (qualitative) screening should become standard procedures for CECs analysis as well as combining analytical methods with metabolomics for the identification of uncommon chemicals, metabolites, and degradation product(s);

- To determine and predict trends, multivariate statistical methods (factor analysis of principal component analysis (PCA) were applied as well as indicators of pollution status, as Hazard Quotient (HQ), Enrichment Factor (EF), Geo-accumulation index (Igeo), and Ecological risk index (RI) were determined in several papers concerning persistent pollutants as PAHs, OCPs, and metals [2,46,51,84,100,107,121,144];

- $\quad$ Regarding CECs, the basis for risk assessment was rarely discussed. Risk coefficients (RQ) value based on the ratio of the Predicted/Measured Environmental Concentration (PEC/MEC) and Predicted No-Effect Concentration (PNEC) was performed in three papers for endocrine disruptors $[61,68,69]$ and in one for pharmaceuticals, pesticides, and other CECs [26]; the fate of pesticides in sediments and risk assessment according to their physico-chemical properties was discussed in one paper [44];

- Spatial distribution of the contaminants was highlighted in several publications [45, 49,53,61,100];

- Pollution emission sources were investigated for PAHs [96], OPCs [94], pharmaceuticals [51,53], and heavy metals $[106,126,128,156]$. Untreated and inadequate treated waste water was demonstrated as being the main source of organic pollution in the low Danube basin. The metals pollution is associated with industrial and municipal sources;

- Seasonal variations were reported for all contaminants classes, probably due to the temperature related processes of biotransformation and absorption. Similar phenomena were reported for pharmaceuticals in Swedish aquatic environment [157] and for herbicide and insecticide in surface waters in Spain [158];

- The Dniester River is one of the less-studied rivers in Europe; 
- $\quad$ No report was identified concerning pharmaceuticals residues in seawater or sediments for the North-West Black Sea coast;

- Studies were heterogeneous and, generally, did not allow comparisons;

- The pollution level in the Lower Danube basin was in agreement with other European rivers such as the Rivers Elbe (Germany) [159], Lis (Portugal) [160], or Po (Italy) [161];

- $\quad$ Future research should be conducted in the investigation on the effect of emerging pollutants mixtures to different biological systems, on the development of bacterial resistance, and the fate of CECs in the environment (transport, bioaccumulation, degradation). Effective wastewater treatment and reliable fate and toxicity assessment are needed.

\section{Conclusions}

It is unrealistic to believe that monitoring and screening programs of today can embrace all known pollutants. However, in recent years, important steps have been taken toward improving analytical methods, risk-assessment approaches, and regulatory bases.

The publications herein reviewed revealed the occurrence and spatial distribution of persistent and emerging micropollutants in surface waters, sediments, and biota in the Low Danube basin and North West Black Sea region. The current situation of these aquatic environments is of great importance in light of the recent EU Directives.

This review showed that pharmaceuticals were determined in the area of study in the following decreasing order of concentrations: carbamazepine $>$ sulfamethoxazole $>$ diclofenac $>$ trimethoprim $>$ ibuprofen. Regarding pesticides, the highest concentrations were reported for carbendazim $>$ metalochlor $>$ atrazine. The reported metals, in the following decreasing order of concentration, were: $\mathrm{Fe}>\mathrm{Zn}>\mathrm{Cu}>\mathrm{Pb}>\mathrm{Cr}>\mathrm{Ni}>\mathrm{As}>\mathrm{Cd}>\mathrm{Hg}$.

These findings show that further studies concerning the fate and bioaccumulation capacity of the contaminants in different environmental compartments (water, sediment, and biota) are needed in order to predict their possible impact to non-target organisms.

Author Contributions: Conceptualization, C.L.C. and A.E.; methodology, A.E., C.L.C. and E.-I.G.; software, E.-I.G.; validation, A.E.; formal analysis, E.-I.G.; investigation, C.L.C. and A.E.; resources, A.E.; writing—original draft preparation, C.L.C.; writing—review and editing, A.E., E.-I.G., A.M.V. and C.T.C.; visualization, A.E., E.-I.G., A.M.V. and C.T.C.; supervision, A.E.; project administration, A.E.; funding acquisition, A.E. All authors have read and agreed to the published version of the manuscript.

Funding: The APC is funded by “Dunarea de Jos” University of Galati, Romania.

Institutional Review Board Statement: Not applicable.

Informed Consent Statement: Not applicable.

Data Availability Statement: Not applicable.

Acknowledgments: This research was performed in the frame of the project with code BSB 27MONITOX (2018-2021), financed through the Joint Operational Programme Black Sea Basin 2014-2020 of European Union. The IEG and CTC work was supported by the Romanian Ministry of Research and Innovation, grant number PN 19110303 "Advanced techniques for identifying sources of contamination and biochemical reactions in aquatic ecosystems".

Conflicts of Interest: The authors declare no conflict of interest.

\section{References}

1. River Basin I ICPDR - International Commission for the Protection of the Danube River. Available online: https://www.icpdr. $\mathrm{org} / \mathrm{main} /$ danube-basin/river-basin (accessed on 5 July 2021).

2. Covaci, A.; Gheorghe, A.; Hulea, O.; Schepens, P. Levels and Distribution of Organochlorine Pesticides, Polychlorinated Biphenyls and Polybrominated Diphenyl Ethers in Sediments and Biota from the Danube Delta, Romania. Environ. Pollut. 2006, 140, 136-149. [CrossRef] [PubMed]

3. Rouholahnejad, E.; Abbaspour, K.C.; Srinivasan, R.; Bacu, V.; Lehmann, A. Water resources of the Black Sea Basin at high spatial and temporal resolution. Water Resour. Res. 2014, 50, 5866-5885. [CrossRef] 
4. Bănăduc, D.; Rey, S.; Trichkova, T.; Lenhardt, M.; Curtean-Bănăduc, A. The Lower Danube River-Danube Delta-North West Black Sea: A Pivotal Area of Major Interest for the Past, Present and Future of Its Fish Fauna-A Short Review. Sci. Total Environ. 2016, 545-546, 137-151. [CrossRef] [PubMed]

5. Gasparotti, C. The Main Factors of Water Pollution in Danube River Basin. EuroEconomica 2014, 1, 91-106.

6. Convention on Cooperation for the Protection and Sustainable Use of the Danube River (Danube River Protection Convention). ICPDR, Sofia, Bulgaria. 1994. Available online: https://www.icpdr.org/main/icpdr/danube-river-protection-convention (accessed on 5 July 2021).

7. Slobodnik, J.; von der Ohe, P.C. Identification of the Danube River Basin Specific Pollutants and Their Retrospective Risk Assessment. In The Danube River Basin; Liska, I., Ed.; The Handbook of Environmental Chemistry; Springer: Berlin/Heidelberg, Germany, 2015; pp. 95-110. ISBN 978-3-662-47739-7.

8. Chapman, D.V.; Bradley, C.; Gettel, G.M.; Hatvani, I.G.; Hein, T.; Kovács, J.; Liska, I.; Oliver, D.M.; Tanos, P.; Trásy, B.; et al. Developments in Water Quality Monitoring and Management in Large River Catchments Using the Danube River as an Example. Environ. Sci. Policy 2016, 64, 141-154. [CrossRef]

9. Avar, P.; Zrínyi, Z.; Maász, G.; Takátsy, A.; Lovas, S.; László, G.; Pirger, Z. $\beta$-Estradiol and Ethinyl-Estradiol Contamination in the Rivers of the Carpathian Basin. Environ. Sci. Pollut. Res. 2016, 23, 11630-11638. [CrossRef]

10. Chitescu, C.L.; Kaklamanos, G.; Nicolau, A.I.; Stolker, A.A.M.L. High Sensitive Multiresidue Analysis of Pharmaceuticals and Antifungals in Surface Water Using U-HPLC-Q-Exactive Orbitrap HRMS. Application to the Danube River Basin on the Romanian Territory. Sci. Total Environ. 2015, 532, 501-511. [CrossRef]

11. Nagy, A.S.; Simon, G.; Szabó, J.; Vass, I. Polycyclic Aromatic Hydrocarbons in Surface Water and Bed Sediments of the Hungarian Upper Section of the Danube River. Environ. Monit. Assess. 2013, 185, 4619-4631. [CrossRef]

12. Vrana, B.; Klučárová, V.; Benická, E.; Abou-Mrad, N.; Amdany, R.; Horáková, S.; Draxler, A.; Humer, F.; Gans, O. Passive Sampling: An Effective Method for Monitoring Seasonal and Spatial Variability of Dissolved Hydrophobic Organic Contaminants and Metals in the Danube River. Environ. Pollut. 2014, 184, 101-112. [CrossRef]

13. Kondor, A.C.; Jakab, G.; Vancsik, A.; Filep, T.; Szeberényi, J.; Szabó, L.; Maász, G.; Ferincz, Á.; Dobosy, P.; Szalai, Z. Occurrence of Pharmaceuticals in the Danube and Drinking Water Wells: Efficiency of Riverbank Filtration. Environ. Pollut. 2020, $265,114893$. [CrossRef]

14. Seitz, W.; Winzenbacher, R. A Survey on Trace Organic Chemicals in a German Water Protection Area and the Proposal of Relevant Indicators for Anthropogenic Influences. Environ. Monit. Assess. 2017, 189, 244. [CrossRef] [PubMed]

15. Petrović, M.; Škrbić, B.; Živančev, J.; Ferrando-Climent, L.; Barcelo, D. Determination of 81 Pharmaceutical Drugs by High Performance Liquid Chromatography Coupled to Mass Spectrometry with Hybrid Triple Quadrupole-Linear Ion Trap in Different Types of Water in Serbia. Sci. Total Environ. 2014, 468-469, 415-428. [CrossRef] [PubMed]

16. Varga, R.; Somogyvári, I.; Eke, Z.; Torkos, K. Seasonal Monitoring of Cardiovascular and Antiulcer Agents' Concentrations in Stream Waters Encompassing a Capital City. J. Pharm. 2013, 2013, 753928. [CrossRef] [PubMed]

17. Subedi, B.; Du, B.; Chambliss, C.K.; Koschorreck, J.; Rüdel, H.; Quack, M.; Brooks, B.W.; Usenko, S. Occurrence of Pharmaceuticals and Personal Care Products in German Fish Tissue: A National Study. Environ. Sci. Technol. 2012, 46, 9047-9054. [CrossRef]

18. Ilie, M.; Marinescu, F.; Ghiță, G.; Deák, G.; Tociu, C.; Matei, M.; Holban, E.; Raischi, M.; Zamfir, S.; Cirstinoiu, C. Evaluation of Emerging Contaminants in Drinking Water and Wastewater in South Romania. Int. J. Environ. Sci. 2017, 2, $108-113$.

19. Higley, E.; Grund, S.; Jones, P.D.; Schulze, T.; Seiler, T.-B.; Lübcke-von Varel, U.; Brack, W.; Wölz, J.; Zielke, H.; Giesy, J.P.; et al. Endocrine Disrupting, Mutagenic, and Teratogenic Effects of Upper Danube River Sediments Using Effect-Directed Analysis. Environ. Toxicol. Chem. 2012, 31, 1053-1062. [CrossRef]

20. Milanović, M.; Sudji, J.; Grujic, N.; Radonic, J.; Turk-Sekulić, M.; Miloradov, M.; Milic, N. Seasonal Variations of Bisphenol A in the Danube by the Novi Sad Municipality, Serbia. J. Serbian Chem. Soc. 2015, 81, 95. [CrossRef]

21. Grund, S.; Higley, E.; Schönenberger, R.; Suter, M.; Braunbeck, T.; Hecker, M.; Hollert, H. The Endocrine Disrupting Potential of Sediments from the Upper Danube River (Germany) as Revealed by in Vitro Bioassays and Chemical Analysis. Environ. Sci. Pollut. Res. Int. 2011, 18, 446-460. [CrossRef]

22. Ene, A.; Denga, Y.; Bogdevich, O.; Zubcov, E. (Eds.) Atlas of Maps; Tehnopress: Iasi, Romania, 2015; Available online: https: //www.researchgate.net/publication/305317824_Atlas_of_Maps (accessed on 10 June 2021)ISBN 978-606-687-235-5.

23. Milić, N.; Sudji, J.; Milanović, M.; Grujić Letić, N.; Radonić, J.; Sekulić, M.T.; Vojinović Miloradov, M.; Mihajlović, I. The determination of bisphenol a in the Danube in the vicinity of Novi-Sad, Serbia. Ann. West Univ. Timis. Ser. Chem. 2012, 22, 7-12.

24. László, F. Pollution by Heavy Metals in the Danube River Basin. In The Danube River Basin; Liska, I., Ed.; The Handbook of Environmental Chemistry; Springer: Berlin/Heidelberg, Germany, 2015; pp. 85-93. ISBN 978-3-662-47739-7.

25. Woitke, P.; Wellmitz, J.; Helm, D.; Kube, P.; Lepom, P.; Litheraty, P. Analysis and assessment of heavy metal pollution in suspended solids and sediments of the river Danube. Chemosphere 2003, 51, 633-642. [CrossRef]

26. Diamanti, K.S.; Alygizakis, N.A.; Nika, M.-C.; Oswaldova, M.; Oswald, P.; Thomaidis, N.S.; Slobodnik, J. Assessment of the Chemical Pollution Status of the Dniester River Basin by Wide-Scope Target and Suspect Screening Using Mass Spectrometric Techniques. Anal. Bioanal. Chem. 2020, 412, 4893-4907. [CrossRef]

27. Joint Danube Survey 4 (JDS4) Scientific Report. Liška, I.; Wagner, F.; Sengl, M.; Deutsch, K.; Slobodník, J.; Paunović, M. (Eds.) ICPDR-International Commission for the Protection of the Danube River: Vienna, Austria, 2021; ISBN 978-3-200-07450-7. 
28. Abdulrazaq, Y.; Abdulsalam, A.; Rotimi, A.L.; Abdulbasit, A.A.; Clifford, O.; Abdulsalam, O.A.; Racheal, O.N.; Joy, A.A.; Victor, F.O.; Johannes, Z.M.; et al. Classification, Potential Routes and Risk of Emerging Pollutants/Contaminant; IntechOpen: London, UK, 2020; ISBN 978-1-83962-419-3.

29. Bilal, M.; Adeel, M.; Rasheed, T.; Zhao, Y.; Iqbal, H.M.N. Emerging Contaminants of High Concern and Their Enzyme-Assisted Biodegradation-A Review. Environ. Int. 2019, 124, 336-353. [CrossRef]

30. Gogoi, A.; Mazumder, P.; Tyagi, V.K.; Tushara Chaminda, G.G.; An, A.K.; Kumar, M. Occurrence and Fate of Emerging Contaminants in Water Environment: A Review. Groundw. Sustain. Dev. 2018, 6, 169-180. [CrossRef]

31. Caldwell, D.J.; Mastrocco, F.; Margiotta-Casaluci, L.; Brooks, B.W. An Integrated Approach for Prioritizing Pharmaceuticals Found in the Environment for Risk Assessment, Monitoring and Advanced Research. Chemosphere 2014, 115, 4-12. [CrossRef]

32. Rudén, C.; Hansson, S.O. Registration, Evaluation, and Authorization of Chemicals (REACH) Is but the First Step-How Far Will It Take Us? Six Further Steps to Improve the European Chemicals Legislation. Environ. Health Perspect. 2010, 118, 6-10. [CrossRef]

33. Dulio, V.; Slobodnik, J. In Response: The NORMAN Perspectives on Prioritization of Emerging Pollutants. Environ. Toxicol. Chem. 2015, 34, 2183-2185. [CrossRef] [PubMed]

34. Anna, S.; Sofia, B.; Christina, R.; Magnus, B. The Dilemma in Prioritizing Chemicals for Environmental Analysis: Known versus Unknown Hazards. Environ. Sci. Process. Impacts 2016, 18, 1042-1049. [CrossRef] [PubMed]

35. Directive 2013/39/EU of the European Parliament and of the Council of 12 August 2013 Amending Directives 2000/60/EC and 2008/105/EC as Regards Priority Substances in the Field of Water Policy; OJEU: Aberdeen, UK, 2013.

36. Commission Implementing Decision (EU) 2018/840-Of 5 June 2018-Establishing a Watch List of Substances for Union-Wide Monitoring in the Field of Water Policy Pursuant to Directive 2008/105/EC of the European Parliament and of the Council and Repealing Commission Implementing Decision (EU); L 495; OJEU: Aberdeen, UK, 2015.

37. Commission Implementing Decision (EU) 2020/1161 of 4 August 2020 Establishing a Watch List of Substances for Union-Wide Monitoring in the Field of Water Policy Pursuant to Directive 2008/105/EC of the European Parliament and of the Council (Notified under Document Number C(2020) 5205); L 257; OJEU: Aberdeen, UK, 2020.

38. Summary of the Final Report Joint Danube Survey 1; ICPDR-International Commission for the Protection of the Danube River: Vienna, Austria, 2002.

39. Radović, T.; Grujić, S.; Petković, A.; Dimkić, M.; Laušević, M. Determination of Pharmaceuticals and Pesticides in River Sediments and Corresponding Surface and Ground Water in the Danube River and Tributaries in Serbia. Environ. Monit. Assess. 2015, 187, 4092. [CrossRef]

40. Patel, M.; Kumar, R.; Kishor, K.; Mlsna, T.; Pittman, C.U.; Modan, D. Pharmaceuticals of Emerging Concern in Aquatic Systems: Chemistry, Occurrence, Effects, and Removal Methods. Chem. Rev. 2019, 119, 3510-3673. [CrossRef]

41. Himmelsbach, M.; Klampfl, C.W.; Buchberger, W. Development of an Analytical Method for the Determination of Antidepressants in Water Samples by Capillary Electrophoresis with Electrospray Ionization Mass Spectrometric Detection. J. Sep. Sci. 2005, 28, 1735-1741. [CrossRef] [PubMed]

42. Fenz, R.; Blaschke, A.P.; Clara, M.; Kroiss, H.; Mascher, D.; Zessner, M. Monitoring of Carbamazepine Concentrations in Wastewater and Groundwater to Quantify Sewer Leakage. Water Sci. Technol. 2005, 52, 205-213. [CrossRef]

43. Joint Danube Survey 2, Final Scientific Report; Liška, I.; Wagner, F. (Eds.) ICPDR-International Commission for the Protection of the Danube River: Vienna, Austria, 2008.

44. Matić Bujagić, I.; Grujić, S.; Laušević, M.; Hofmann, T.; Micić, V. Emerging Contaminants in Sediment Core from the Iron Gate I Reservoir on the Danube River. Sci. Total Environ. 2019, 662, 77-87. [CrossRef]

45. Loos, R.; Tavazzi, S.; Mariani, G.; Suurkuusk, G.; Paracchini, B.; Umlauf, G. Analysis of Emerging Organic Contaminants in Water, Fish and Suspended Particulate Matter (SPM) in the Joint Danube Survey Using Solid-Phase Extraction Followed by UHPLC-MS-MS and GC-MS Analysis. Sci. Total Environ. 2017, 607-608, 1201-1212. [CrossRef] [PubMed]

46. Letić, N.N.G.; Milanović, M.L.; Milić, N.B.; Miloradov, M.B.V.; Radonić, J.R.; Mihajlović, I.J.; Sekulić, M.M.T. Determination of Emerging Substances in the Danube and Potential Risk Evaluation. CLEAN-Soil Air Water 2015, 43, 731-738. [CrossRef]

47. Milić, N.; Milanović, M.; Radonić, J.; Turk Sekulić, M.; Mandić, A.; Orčić, D.; Mišan, A.; Milovanović, I.; Grujić Letić, N.; Vojinović Miloradov, M. The Occurrence of Selected Xenobiotics in the Danube River via LC-MS/MS. Environ. Sci. Pollut. Res. 2018, 25, 11074-11083. [CrossRef] [PubMed]

48. Radović, T.; Grujić, S.; Dujaković, N.; Radišić, M.; Vasiljević, T.; Petković, A.; Boreli-Zdravković, Đ.; Dimkić, M.; Laušević, M. Pharmaceutical Residues in the Danube River Basin in Serbia-A Two-Year Survey. Water Sci. Technol. 2012, 66, 659-665. [CrossRef]

49. Loos, R.; Locoro, G.; Contini, S. Occurrence of Polar Organic Contaminants in the Dissolved Water Phase of the Danube River and Its Major Tributaries Using SPE-LC-MS2 Analysis. Water Res. 2010, 44, 2325-2335. [CrossRef]

50. Petre, J.; Iancu, V.I.; Galaon, T.; Simion, M.; Niculescu, M.; Vasile, G.G.; Pascu, L.F.; Lehr, C.B.; Cruceru, L.; Calinescu, S.; et al Occurrence of pharmaceuticals and disinfectants in the dissolved water phase of the Danube river and three major tributaries from Romania. Romanian J. Ecol. Environ. Chem. 2019, 1, 55-65. [CrossRef]

51. Burcea, A.; Boeraş, I.; Mihuţ, C.-M.; Bănăduc, D.; Matei, C.; Curtean-Bănăduc, A. Adding the Mureş River Basin (Transylvania, Romania) to the List of Hotspots with High Contamination with Pharmaceuticals. Sustainability 2020, 12, 10197. [CrossRef]

52. Chitescu, C.L.; Nicolau, A. Preliminary Survey of Pharmaceutical Residues in Some Important Romanian Rivers. Toxicol. Environ. Chem. 2015, 96, 1333-1345. [CrossRef] 
53. Moldovan, Z.; Marincas, O.; Povar, I.; Lupascu, T.; Longree, P.; Rota, J.S.; Singer, H.; Alder, A.C. Environmental Exposure of Anthropogenic Micropollutants in the Prut River at the Romanian-Moldavian Border: A Snapshot in the Lower Danube River Basin. Environ. Sci. Pollut. Res. Int. 2018, 25, 31040-31050. [CrossRef] [PubMed]

54. Fekadu, S.; Alemayehu, E.; Dewil, R.; Van der Bruggen, B. Pharmaceuticals in Freshwater Aquatic Environments: A Comparison of the African and European Challenge. Sci. Total Environ. 2019, 654, 324-337. [CrossRef] [PubMed]

55. Helenkár, A.; Sebők, Á.; Záray, G.; Molnár-Perl, I.; Vasanits-Zsigrai, A. The Role of the Acquisition Methods in the Analysis of the Non-Steroidal Anti-Inflammatory Drugs in Danube River by Gas Chromatography-Mass Spectrometry. Talanta 2010, 82, 600-607. [CrossRef] [PubMed]

56. Ivešić, M.; Krivohlavek, A.; Žuntar, I.; Tolić, S.; Šikić, S.; Musić, V.; Pavlić, I.; Bursik, A.; Galić, N. Monitoring of Selected Pharmaceuticals in Surface Waters of Croatia. Environ. Sci. Pollut. Res. 2017, 24, 23389-23400. [CrossRef]

57. Faust, M.; Backhaus, T.; Altenburger, R.; Dulio, V.; van Gils, J.; Ginebreda, A.; Kortenkamp, A.; Munthe, J.; Posthuma, L.; Slobodnik, J.; et al. Prioritisation of Water Pollutants: The EU Project SOLUTIONS Proposes a Methodological Framework for the Integration of Mixture Risk Assessments into Prioritisation Procedures under the European Water Framework Directive. Environ. Sci. Eur. 2019, 31, 66. [CrossRef]

58. Joint Danube Survey 3 (JDS3) Scientific Report; Liška, I.; Wagner, F.; Sengl, M.; Deutsch, K.; Slobodník, J. (Eds.) ICPDR-International Commission for the Protection of the Danube River: Vienna, Austria, 2015.

59. Graca, B.; Staniszewska, M.; Zakrzewska, D. Reconstruction of the pollution history of alkylphenols (4-tert-octylphenol, 4nonylphenol) in the Baltic Sea. Environ. Sci. Pollut. Res. 2016, 23, 11598-11610. [CrossRef]

60. Emerging Substances I NORMAN. Available online: https://www.norman-network.net/?q=node/19 (accessed on 8 July 2021 ).

61. Čelić, M.; Škrbić, B.D.; Insa, S.; Živančev, J.; Gros, M.; Petrović, M. Occurrence and Assessment of Environmental Risks of Endocrine Disrupting Compounds in Drinking, Surface and Wastewaters in Serbia. Environ. Pollut. 2020, 262, 114344. [CrossRef]

62. Kuch, H.M.; Ballschmiter, K. Determination of Endocrine-Disrupting Phenolic Compounds and Estrogens in Surface and Drinking Water by HRGC-(NCI)-MS in the Picogram per Liter Range. Environ. Sci. Technol. 2001, 35, 3201-3206. [CrossRef]

63. Steroid Estrogens Profiles along River Stretches Arising from Sewage Treatment Works Discharges I Environmental Science \& Technology. Available online: https:/ / pubs.acs.org/doi/10.1021/es0202107 (accessed on 8 July 2021).

64. Dorabawila, N.; Gupta, G. Endocrine Disrupter-Estradiol—in Chesapeake Bay Tributaries. J. Hazard. Mater. 2005, 120, 67-71. [CrossRef]

65. Antonijevic, M.; Arsovic, M.; Cáslavský, J.; Cvetkovic, V.; Dabic, P.; Franko, M.; Ilic, G.; Ivanovic, M.; Ivanovic, N.; Kosovac, M.; et al. Actual Contamination of the Danube and Sava Rivers at Belgrade (2013). J. Serbian Chem. Soc. 2014, 79, 1169-1184. [CrossRef]

66. Galaon, T.; Petre, J.; Iancu, V.I.; Cruceru, L.; Vasile, G.G.; Pascu, L.F.; Lehr, C.B. Detection of Estrogen Hormones in Danube River and Tributaries Using Liquid Chromatography-Mass Spectrometry. Rev. Chem. 2016, 67, 1474-1478.

67. Chiriac, F.L.; Paun, I.; Pirvu, F.; Pascu, L.F.; Galaon, T. Occurrence and Fate of Bisphenol A and Its Congeners in Two Wastewater Treatment Plants and Receiving Surface Waters in Romania. Environ. Toxicol. Chem. 2021, 40, 435-446. [CrossRef] [PubMed]

68. Chiriac, F.L.; Paun, I.; Iancu, V.-I.; Pirvu, F.; Niculescu, M.; Galaon, T. Occurrence of Phenolic Endocrine Disruptors in Danube Delta, Romania. Rev. Chim. 2020, 71, 316-324. [CrossRef]

69. Chiriac, F.L.; Pirvu, F.; Paun, I. Investigation of Endocrine Disruptor Pollutants and Their Metabolites along the Romanian Black Sea Coast: Occurrence, Distribution and Risk Assessment. Environ. Toxicol. Pharmacol. 2021, 86, 103673. [CrossRef] [PubMed]

70. Pignotti, E.; Farré, M.; Barceló, D.; Dinelli, E. Occurrence and Distribution of Six Selected Endocrine Disrupting Compounds in Surface- and Groundwaters of the Romagna Area (North Italy). Environ. Sci. Pollut. Res. 2017, 24, 21153-21167. [CrossRef]

71. Anđelić, I.; Roje-Busatto, R.; Ujević, I.; Vuletić, N.; Matijević, S. Distribution of Bisphenol A in Sediment and Suspended Matter and Its Possible Impact on Marine Life in Kaštela Bay, Adriatic Sea, Croatia. J. Mar. Sci. Eng. 2020, 8, 480. [CrossRef]

72. Directive 2006/118/EC of the European Parliament and of the Council of 12 December 2006 on the Protection of Groundwater against Pollution and Deterioration; L 327; OJEU: Aberdeen, UK, 2006.

73. Council Directive 98/83/EC of 3 November 1998 on the Quality of Water Intended for Human Consumption; L 330; OJEU: Aberdeen, UK, 1998.

74. Directive 2000/60/EC of the European Parliament and of the Council of 23 October 2000 Establishing a Framework for Community Action in the Field of Water Policy; L 327; OJEU: Aberdeen, UK, 2000.

75. Commission Implementing Decision (EU) 2015/495 of 20 March 2015 Establishing a Watch List of Substances for Union-Wide Monitoring in the Field of Water Policy Pursuant to Directive 2008/105/EC of the European Parliament and of the Council (Notified under Document C(2015) 1756); L 78; OJEU: Aberdeen, UK, 2015.

76. Ccanccapa, A.; Masiá, A.; Navarro-Ortega, A.; Picó, Y.; Barceló, D. Pesticides in the Ebro River Basin: Occurrence and Risk Assessment. Environ. Pollut. 2016, 211, 414-424. [CrossRef]

77. Antić, N.; Radišić, M.; Radović, T.; Vasiljević, T.; Grujić, S.; Petković, A.; Dimkić, M.; Laušević, M. Pesticide Residues in the Danube River Basin in Serbia-A Survey during 2009-2011. CLEAN—Soil Air Water 2015, 43, 197-204. [CrossRef]

78. Regulation (EC) No 850/2004 of the European Parliament and of the Council of 29 April 2004 on Persistent Organic Pollutants and Amending Directive 79/117/EEC; L 158; OJEU: Aberdeen, UK, 2004.

79. Stockholm Convention-Home Page. Available online: http://chm.pops.int/ (accessed on 13 July 2021). 
80. Directive 2008/105/EC of the European Parliament and of the Council of 16 December 2008 on Environmental Quality Standards in the Field of Water Policy, Amending and Subsequently Repealing Council Directives 82/176/EEC, 83/513/EEC, 84/156/EEC, 84/491/EEC, 86/280/EEC and Amending Directive 2000/60/EC of the European Parliament and of the Council; L 348; OJEU: Aberdeen, UK, 2008.

81. U.S. EPA. Provisional Guidance for Quantitative Risk Assessment of Polycyclic Aromatic Hydrocarbons (PAH). Available online: https:/ / cfpub.epa.gov/ncea/risk/recordisplay.cfm?deid=49732 (accessed on 17 July 2021).

82. Commission Regulation (EU) No 1259/2011 of 2 December 2011 Amending Regulation (EC) No 1881/2006 as Regards Maximum Levels for Dioxins, Dioxin-like PCBs and Non Dioxin-like PCBs in Foodstuffs Text with EEA Relevance; L 320/18; OJEU: Aberdeen, UK, 2011.

83. Stoichev, T.; Makedonski, L.; Trifonova, T.; Stancheva, M.; Ribarova, F. DDT in Fish from the Bulgarian Region of the Black Sea. Chem. Ecol. 2007, 23, 191-200. [CrossRef]

84. Dubovina, M.; Krčmar, D.; Grba, N.; Watson, M.A.; Rađenović, D.; Tomašević-Pilipović, D.; Dalmacija, B. Distribution and Ecological Risk Assessment of Organic and Inorganic Pollutants in the Sediments of the Transnational Begej Canal (SerbiaRomania). Environ. Pollut. 2018, 236, 773-784. [CrossRef]

85. Radu, M.; Ionescu, P.; Alexandru Anton, I.; Deak, G.; Marcu, E.; Ciobotaru, I.-E.; Diacu, E.; Pipirigeanu, M. Assessment of Contamination with Hazardous Substances in Surface Sediments in the Lower Danube River. Technium 2020, 1, 37-44. [CrossRef]

86. Stancheva, M.; Makedonski, L.; Georgieva, S. Organochlorine Pesticides in Fish from Bulgarian Region of Black Sea. Arch. Balk. Med. Union 2011, 46, 209.

87. Nagy, A.S.; Szabó, J.; Vass, I. Occurrence and Distribution of Polycyclic Aromatic Hydrocarbons in Surface Water and Sediments of the Danube River and Its Tributaries, Hungary. J. Environ. Sci. Health Part A Tox. Hazard. Subst. Environ. Eng. 2014, 49, 1134-1141. [CrossRef]

88. Patrolecco, L.; Ademollo, N.; Capri, S.; Pagnotta, R.; Polesello, S. Occurrence of Priority Hazardous PAHs in Water, Suspended Particulate Matter, Sediment and Common Eels (Anguilla Anguilla) in the Urban Stretch of the River Tiber (Italy). Chemosphere 2010, 81, 1386-1392. [CrossRef]

89. Kanzari, F.; Syakti, A.D.; Asia, L.; Malleret, L.; Piram, A.; Mille, G.; Doumenq, P. Distributions and Sources of Persistent Organic Pollutants (Aliphatic Hydrocarbons, PAHs, PCBs and Pesticides) in Surface Sediments of an Industrialized Urban River (Huveaune), France. Sci. Total Environ. 2014, 478, 141-151. [CrossRef] [PubMed]

90. Liu, Y.; Beckingham, B.; Ruegner, H.; Li, Z.; Ma, L.; Schwientek, M.; Xie, H.; Zhao, J.; Grathwohl, P. Comparison of Sedimentary PAHs in the Rivers of Ammer (Germany) and Liangtan (China): Differences between Early- and Newly-Industrialized Countries. Environ. Sci. Technol. 2013, 47, 701-709. [CrossRef] [PubMed]

91. Pérez-Fernández, B.; Viñas, L.; Franco, M.Á.; Bargiela, J. PAHs in the Ría de Arousa (NW Spain): A Consideration of PAHs Sources and Abundance. Mar. Pollut. Bull. 2015, 95, 155-165. [CrossRef] [PubMed]

92. Vosniakos, F.; Pascu, L.; Petre, J.; Cruceru, L.; Vasile, G.; Iancu, V.; Cristina, D.; Niculescu, M.; Niculae, A.; Nicolau, M.; et al. The temporal and spatial monitoring of water and sediment physical-chemical quality from Saint Feorge branch in the period February 2009-February 2011. Fresenius Environ. Bull. 2012, 21, 13.

93. Strbac, S.; Stojic, N.; Pucarevic, M.; Bajic, B. Organochlorine Pesticides in the Tisza River (Serbia): Distribution and Risk Assessment. Zb. Matice Srp. Prir. Nauke 2019, 113-122. [CrossRef]

94. Brboric, M.; Radonic, J.; Miloradov, M.; Pap, S.; Turk Sekulić, M. Organochlorine Contamination in Sediments Collected from a Rural-, Urban- and Industrial-Impacted Aquatic System (Danube, Serbia). Holist. Approach Environ. 2020, 10, 41-47. [CrossRef]

95. Škrbić, B.D.; Kadokami, K.; Antić, I.; Jovanović, G. Micro-Pollutants in Sediment Samples in the Middle Danube Region, Serbia: Occurrence and Risk Assessment. Environ. Sci. Pollut. Res. 2018, 25, 260-273. [CrossRef]

96. Beldean-Galea, M.; Mihaiescu, R.; Arghius, V.; Croitoru, A.; Horvath, C.; Coman, V. Occurrence and Sources of Polycyclic Aromatic Hydrocarbons in the Tisza River and Its Romanian Tributaries. Water. Air. Soil Pollut. 2016, 227, 377. [CrossRef]

97. Micić, V.; Kruge, M.A.; Hofmann, T. Variations of Common Riverine Contaminants in Reservoir Sediments. Sci. Total Environ. 2013, 458-460, 90-100. [CrossRef]

98. Ene, A.; Bogdevich, O.; Sion, A. Levels and Distribution of Organochlorine Pesticides (OCPs) and Polycyclic Aromatic Hydrocarbons (PAHs) in Topsoils from SE Romania. Sci. Total Environ. 2012, 439, 76-86. [CrossRef] [PubMed]

99. Ciornea, V.; Ivanova, A.; Elena, Z.; Ene, A. Determination of Some Organochlorine Pesticides in the Waters of the Prut River. Ann. Univ. Dunarea Galati Fascicle II 2016, 8, 81-85.

100. Ivanova, A.; Wiberg, K.; Ahrens, L.; Zubcov, E.; Dahlberg, A.-K. Spatial Distribution of Legacy Pesticides in River Sediment from the Republic of Moldova. Chemosphere 2021, 279, 130923. [CrossRef]

101. Bogdevich, O.; Ene, A.; Cadocinicov, O.; Culighin, E. The analysis of old pesticides and PAHs pollution sources in Low Danube region. J. Int. Sci. Publ. Ecol. Saf. 2013, 7, 233-243.

102. Ţigănuş, D.; Coatu, V.; Lazăr, L.; Oros, A.; Spînu, A.D. Identification of the sources of polycyclic aromatic hydrocarbons in sediments from the Romanian Black Sea sector. Cercet. Mar. 2013, 43, 187-196.

103. State of the Environment of the Black Sea 2009-2014/5; Commission on the Protection of the Black Sea Against Pollution: Istabul, Turkey, 2019; ISBN 978-605-84837-0-5.

104. Monchanin, C.; Devaud, J.M.; Barron, A.B.; Lihoreau, M. Current permissible levels of metal pollutants harm terrestrial invertebrates. Sci.Total Environ. 2021, 779, 146398. [CrossRef]

105. Ali, H.; Khan, E.; Ilahi, I. Environmental Chemistry and Ecotoxicology of Hazardous Heavy Metals: Environmental Persistence, Toxicity, and Bioaccumulation. J. Chem. 2019, 2019, e6730305. [CrossRef] 
106. Sakan, S.M. Trace Element Study In Tisa River and Danube Alluvial Sediment in Serbia. Int. J. Sediment Res. 2013, 28, 12. [CrossRef]

107. Iordache, A.M.; Nechita, C.; Pluhacek, T.; Iordache, M.; Zgavarogea, R.; Ionete, R.E. Past and Present Anthropic Environmental Stress Reflect High Susceptibility of Natural Freshwater Ecosystems in Romania. Environ. Pollut. 2020, 267, 115505. [CrossRef]

108. Subotić, S. Heavy Metal and Trace Element Bioaccumulation in Target Tissues of Four Edible Fish Species from the Danube River (Serbia). Ecotoxicol. Environ. Saf. 2013, 98, 196-202. [CrossRef]

109. Milošković, A.; Dojčinović, B.; Kovačević, S.; Radojković, N.; Radenković, M.; Milošević, D.; Simić, V. Spatial Monitoring of Heavy Metals in the Inland Waters of Serbia: A Multispecies Approach Based on Commercial Fish. Environ. Sci. Pollut. Res. 2016, 23, 9918-9933. [CrossRef]

110. Milanov, Đ.; Krstić, M.; Markovic, R.; Jovanovic, D.; Baltic, M.; Ćirić, J.; Jovetic, M.; Baltić, Ž. Analysis of Heavy Metals Concentration in Tissues of Three Different Fish Species Included in Human Diet from Danube River. Acta Vet. 2016, 66, 89-102. [CrossRef]

111. Lavrova, S.; Georgieva, S.; Gartsiyanova, K. Assessment of the metal concentration in Yantra river within an area with active anthropogenic influence. For. Ideas 2020, 26, 326-340.

112. Pantelica, A.; Ene, A.; Georgescu, I. Instrumental Neutron Activation Analysis of Some Fish Species from Danube River in Romania. Microchem. J. 2012, 103, 142-147. [CrossRef]

113. Ilie, M.; Marinescu, F.; Ghita, G.; Deak, G.; Tanase, S.; Raischi, M. Assessment of Heavy Metal in Water and Sediments of the Danube River. J. Environ. Prot. Ecol. 2014, 15, 825.

114. Simionov, I.-A.; Cristea, V.; Petrea, S.M.; Mogodan Antache, A.; Aurelia, N.; Strungaru, S.-A.; Ene, A.; Sarpe, D. Heavy metal evaluation in the lower sector of Danube river. Sci. Pap. Ser. E Land Reclam. Earth Obs. Surv. Environ. Eng. 2020, 11, 11-16.

115. Bravo, A.; Loizeau, J.-L.; Dranguet, P.; Makri, S.; Björn, E.; Ungureanu, G.; Slaveykova, V.I.; Cosio, C. Persistent Hg Contamination and Occurrence of Hg-Methylating Transcript (HgcA) Downstream of a Chlor-Alkali Plant in the Olt River (Romania). Environ. Sci. Pollut. Res. 2016, 23, 10529-10541. [CrossRef]

116. Assessment of Heavy Metals Pollution in Sediments from Reservoirs of the Olt River as Tool for Environmental Risk Management. Rev. Chim. 2020, 70, 4153-4162. [CrossRef]

117. Ioniţă, C.; Magdalena, M.; Morosan, E. Analysis of Heavy Metals and Organic Pollutants from Some Danube River Fishes. Farmacia 2014, 62, 299-305.

118. Matache, M.L.; Marin, C.; Rozylowicz, L.; Tudorache, A. Plants Accumulating Heavy Metals in the Danube River Wetlands. J. Environ. Health Sci. Eng. 2013, 11, 39. [CrossRef] [PubMed]

119. Calmuc, V.A.; Calmuc, M.; Arseni, M.; Topa, C.M.; Timofti, M.; Burada, A.; Iticescu, C.; Georgescu, L.P. Assessment of Heavy Metal Pollution Levels in Sediments and of Ecological Risk by Quality Indices, Applying a Case Study: The Lower Danube River, Romania. Water 2021, 13, 1801. [CrossRef]

120. Begy, R.-C. Sediment Dynamics and Heavy Metal Pollution History of the Cruhlig Lake (Danube Delta, Romania). J. Environ. Radioact. 2016, 153, 167-175. [CrossRef]

121. Gati, G.; Pop, C.; Brudaşcă, F.; Gurzău, A.E.; Spînu, M. The Ecological Risk of Heavy Metals in Sediment from the Danube Delta. Ecotoxicology 2016, 25, 688-696. [CrossRef]

122. Burada, A.; Topa, M.-C.; Georgescu, L.; Teodorof, L.; Nastase, C.; Seceleanu-Odor, D.; Negrea, B.; Iticescu, C. Heavy Metals Accumulation in Plankton and Water of Four Aquatic Complexes from Danube Delta Area. AACL Bioflux 2014, 77, 301-310.

123. Burada, A.; Topa, M.-C.; Georgescu, L.; Teodorof, L.; Nastase, C.; Seceleanu-Odor, D.; Iticescu, C. Heavy Metals Environment Accumulation in Somova-Parches Aquatic Complex from the Danube Delta Area. Rev. Chim.-Buchar.-Orig. Ed. 2015, 66, 48-54.

124. Nastase, C.; Teodorof, L.; Burada, A.; Seceleanu-Odor, D.; Tiganus, M.; Tudor, I.; Ibram, O.; Spiridon, C.; Năstase, A.; George, T.; et al. Danube Delta Biosphere Reserve-Ten Years of Toxic Substances Monitoring. Ann. Univ. Dunarea Galati Fascicle II-Math. Phys. Theor. Mech. 2017, 40, 55-60.

125. Strungaru, S.-A.; Nicoara, M.; Teodosiu, C.; Baltag, E.; Ciobanu, C.; Plavan, G. Patterns of Toxic Metals Bioaccumulation in a Cross-Border Freshwater Reservoir. Chemosphere 2018, 207, 192-202. [CrossRef]

126. Simionov, I.-A.; Cristea, D.S.; Petrea, S.-M.; Mogodan, A.; Nicoara, M.; Plavan, G.; Baltag, E.S.; Jijie, R.; Strungaru, S.-A. Preliminary Investigation of Lower Danube Pollution Caused by Potentially Toxic Metals. Chemosphere 2021, 264, 128496. [CrossRef]

127. Trifan, A.; Breabăn, I.G.; Sava, D.; Bucur, L.; Toma, C.-C.; Miron, A. Heavy metal content in macroalgae from Roumanian Black Sea. Rev. Romaine Chim. 2015, 60, 915-920.

128. Jitar, O. Bioaccumulation of Heavy Metals in Marine Organisms from the Romanian Sector of the Black Sea. New Biotechnol. 2015, 32, 10. [CrossRef] [PubMed]

129. Ivanova, K.; Stancheva, M.; Panayotova, V. Determination of Heavy Metals in Black Sea Mytilus Galloprovincialis and Rapana Venosa. Scr. Sci. Med. 2012, 44, 27-30. [CrossRef]

130. Zubcov, E.; Zubcov, N.; Ene, A.; Biletchi, L. Assessment of Copper and Zinc Levels in Fish from Freshwater Ecosystems of Moldova. Environ. Sci. Pollut. Res. Int. 2012, 19, 2238-2247. [CrossRef] [PubMed]

131. ISO 5667-3:2018 Water Quality—Sampling-Part 3: Preservation and Handling of Water Samples. Available online: https: //www.iso.org/cms/render/live/en/sites/isoorg/contents/data/standard/07/23/72370.html (accessed on 11 August 2021).

132. ISO 5667-13:2011 Water Quality—Sampling_Part 13: Guidance on Sampling of Sludges. Available online: https://www.iso.org/ cms/render/live/en/sites/isoorg/contents/data/standard/04/54/45450.html (accessed on 11 August 2021). 
133. ISO 15587-1:2002 Water Quality—Digestion for the Determination of Selected Elements in Water-Part 1: Aqua Regia Digestion. Available online: https://www.iso.org/cms/render/live/en/sites/isoorg/contents/data/standard/03/13/31354.html (accessed on 11 August 2021).

134. ISO 15587-2:2002 Water Quality—Digestion for the Determination of Selected Elements in Water-Part 2: Nitric acid Digestion. Available online: https://www.iso.org/cms/render/live/en/sites/isoorg/contents/data/standard/03/13/31355.html (accessed on 11 August 2021).

135. ISO 17294-2:2016 Water Quality-Application of Inductively Coupled Plasma Mass Spectrometry (ICP-MS). Available online: https://www.iso.org/cms/render/live/en/sites/isoorg/contents/data/standard/06/29/62962.html (accessed on 11 August 2021).

136. ISO 11047:1998 Soil Quality—Determination of Cadmium, Chromium, Cobalt, Copper, Lead, Manganese, Nickel and Zinc—Flame and Electrothermal Atomic Absorption Spectrometric Methods. Available online: https://www.iso.org/cms/render/live/en/ sites/isoorg/contents/data/standard/02/40/24010.html (accessed on 11 August 2021).

137. Simionov, I.-A.; Cristea, V.; Petrea, S.M.; Sarbu, E.; Coada, M.T.; Cristea, D.S. The Presence of Heavy Metals in Fish Meat from Danube River: An Overview. AACL Bioflux. 2016, 9, 12.

138. Order MEWM no 161/2006 of Romanian Ministry of Environment and Water Management regarding Norms for Surface Water Classification in Order to Establish Ecological State of Water Bodies, In Romanian Official Monitor no. 511 (Published in 13 June 2006), Bucharest. Available online: http:/ / www.legex.ro/Ordin-161-2006-71706.aspx (accessed on 12 August 2021).

139. Astatkie, H.; Ambelu, A.; Mengistie, E. Contamination of Stream Sediment With Heavy Metals in the Awetu Watershed of Southwestern Ethiopia. Front. Earth Sci. 2021, 9, 609. [CrossRef]

140. Protano, C.; Zinnà, L.; Giampaoli, S.; Spica, V.R.; Chiavarini, S.; Vitali, M. Heavy Metal Pollution and Potential Ecological Risks in Rivers: A Case Study from Southern Italy. Bull. Environ. Contam. Toxicol. 2014, 92, 75-80. [CrossRef] [PubMed]

141. García-Pereira, F.J.; García Giménez, R.; Vigil de la Villa, R.; Procopio, J.R. Heavy Metal Fractionation in Sediments from the Jarama River (Central Spain). Environ. Earth Sci. 2015, 73, 2385-2396. [CrossRef]

142. Manzetti, S. Heavy Metal Pollution in the Baltic Sea, from the North European Coast to the Baltic States, Finland and the Swedish Coastline to Norway. Fjordforsk AS Tech. Rep. 2020, 6, 90. [CrossRef]

143. Spagnoli, F.; De Marco, R.; Dinelli, E.; Frapiccini, E.; Frontalini, F.; Giordano, P. Sources and Metal Pollution of Sediments from a Coastal Area of the Central Western Adriatic Sea (Southern Marche Region, Italy). Appl. Sci. 2021, 11, 1118. [CrossRef]

144. Teodorof, L.; Burada, A.; Despina, C.; Odor, D.S.; Spiridon, C.; Tigănus,, M.; Tudor, M.I.; Tudor, M.; Ene, A.; Zubcov, E.; et al. Sediments Quality Assessment in Terms of Single and Integrated Indices from Romanian MONITOX Network (2019-2020). Ann. "Dunarea Jos" Univ. Galati Fascicle II Math. Phys. Theor. Mech. 2020, 43, 175-183. [CrossRef]

145. Kirschner, A.K.T.; Reischer, G.H.; Jakwerth, S.; Savio, D.; Ixenmaier, S.; Toth, E.; Sommer, R.; Mach, R.L.; Linke, R.; Eiler, A.; et al. Multiparametric Monitoring of Microbial Faecal Pollution Reveals the Dominance of Human Contamination along the Whole Danube River. Water Res. 2017, 124, 543-555. [CrossRef]

146. Kavka, G.G.; Kasimir, G.D.; Farnleitner, A.H. Microbiological Water Quality of the River Danube (km 2581-km 15): Longitudinal Variation of Pollution as Determined by Standard Parameters; Austrian Committee Danube Research/IAD: Vienna, Austria, 2006; pp. 415-421.

147. Council Directive 91/271/EEC of 21 May 1991 Concerning Urban Waste-Water Treatment; L 135; OJEU: Aberdeen, UK, 1991.

148. Directive 2006/7/EC of the European Parliament and of the Council of 15 February 2006 Concerning the Management of Bathing Water Quality and Repealing Directive 76/160/EEC; L 64; OJEU: Aberdeen, UK, 2006.

149. Directive (EU) 2020/2184 of the European Parliament and of the Council of 16 December 2020 on the Quality of Water Intended for Human Consumption (Recast) (Text with EEA Relevance); L 435; OJEU: Aberdeen, UK, 2020.

150. ISO 9308-2:2012 Water Quality_Enumeration of Escherichia coli and Coliform Bacteria—Part 2: Most Probable Number Method. Available online: https://www.iso.org/cms/render/live/en/sites/isoorg/contents/data/standard/05/22/52246.html (accessed on 18 August 2021).

151. Kirschner, A.; Kavka, G.; Reischer, G.; Sommer, R.; Blaschke, A.; Stevenson, M.; Vierheilig, J.; Mach, R.; Farnleitner, A. Microbiological Water Quality of the Danube River: Status Quo and Future Perspectives. In The Danube River Basin; The Handbook of Environmental Chemistry; Springer: Berlin/Heidelberg, Germany, 2015; Volume 39, pp. 439-468. [CrossRef]

152. Ajeagah, G.; Cioroi, M.; Praisler, M.; Constantin, O.; Palela, M.; Bahrim, G. Bacteriological and Environmental Characterisation of the Water Quality in the Danube River Basin in the Galati Area of Romania. Afr. J. Microbiol. Res. 2012, 6, 292-301. [CrossRef]

153. Ene, A.; Vasile, M.A.; Bahrim, G. Study of Microbiological Contamination Level of Surface Water in MONITOX Network Areas before and after COVID-19 Pandemic. Analele Univ. "Dunărea Jos" Din Galați Fasc. II Mat. Fiz. Mec. Teor. Ann. "Dunarea Jos" Univ. Galati Fascicle II Math. Phys. Theor. Mech. 2020, 43, 75-81. [CrossRef]

154. Vasile, M.A.; Ene, A.; Bahrim, G. Microbiological Quality and Contamination Level of Water of Black Sea and Northern Aegean Sea. In Proceedings of the Environmental Toxicants in Freshwater and Marine Ecosystems in the Black Sea Basin, Kavala, Greece, 8-11 September 2020; Available online: https:/ /ibn.idsi.md/vizualizare_articol/115635 (accessed on 18 July 2021).

155. Kalkan, S.; Altuğ, G. The Composition of Cultivable Bacteria, Bacterial Pollution, and Environmental Variables of the Coastal Areas: An Example from the Southeastern Black Sea, Turkey. Environ. Monit. Assess. 2020, 192, 356. [CrossRef] [PubMed]

156. Pavlovi, P.; Pavlovi, D. Assessment of the Contamination of Riparian Soil and Vegetation by Trace Metals-A Danube River Case Study. Sci. Total Environ. 2016, 540, 396-409. [CrossRef] 
157. Daneshvar, A.; Svanfelt, J.; Kronberg, L.; Prévost, M.; Weyhenmeyer, G.A. Seasonal Variations in the Occurrence and Fate of Basic and Neutral Pharmaceuticals in a Swedish River-Lake System. Chemosphere 2010, 80, 301-309. [CrossRef]

158. Herrero-Hernández, E.; Rodríguez-Cruz, M.S.; Pose-Juan, E.; Sánchez-González, S.; Andrades, M.S.; Sánchez-Martín, M.J. Seasonal Distribution of Herbicide and Insecticide Residues in the Water Resources of the Vineyard Region of La Rioja (Spain). Sci. Total Environ. 2017, 609, 161-171. [CrossRef]

159. Wiegel, S.; Aulinger, A.; Brockmeyer, R.; Harms, H.; Löffler, J.; Reincke, H.; Schmidt, R.; Stachel, B.; von Tümpling, W.; Wanke, A. Pharmaceuticals in the River Elbe and Its Tributaries. Chemosphere 2004, 57, 107-126. [CrossRef] [PubMed]

160. Paíga, P.; Santos, L.H.M.L.M.; Ramos, S.; Jorge, S.; Silva, J.G.; Delerue-Matos, C. Presence of Pharmaceuticals in the Lis River (Portugal): Sources, Fate and Seasonal Variation. Sci. Total Environ. 2016, 573, 164-177. [CrossRef] [PubMed]

161. Ferrari, F.; Gallipoli, A.; Balderacchi, M.; Ulaszewska, M.M.; Capri, E.; Trevisan, M. Exposure of the Main Italian River Basin to Pharmaceuticals. J. Toxicol. 2011, 2011, e989270. [CrossRef] [PubMed] 